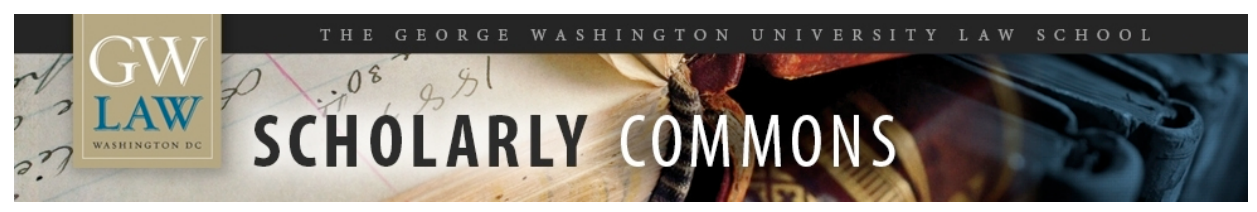

GW Law Faculty Publications \& Other Works

Faculty Scholarship

2010

\title{
Gender, Masculinities and Transition in Conflicted Societies
}

Naomi R. Cahn

George Washington University Law School, ncahn@law.gwu.edu

Fionnuala D. Ni Aolain

Follow this and additional works at: https://scholarship.law.gwu.edu/faculty_publications

Part of the Law Commons

\section{Recommended Citation}

Naomi Cahn \& Fionnuala D. Ni Aolain, Gender, Masculinities and Transition in Conflicted Societies, 44 New Eng. L. Rev. 1 (2010).

This Article is brought to you for free and open access by the Faculty Scholarship at Scholarly Commons. It has been accepted for inclusion in GW Law Faculty Publications \& Other Works by an authorized administrator of Scholarly Commons. For more information, please contact spagel@law.gwu.edu. 


\title{
HIRSCH LECTURE: GENDER, MASCULINITIES, AND TRANSITION IN CONFLICTED SOCIETIES
}

\author{
NAOMI CAHN*
}

FIONNUALA Ní AOLÁIN**

\begin{abstract}
This Article uses a gender lens to explore how conflict affects men and women differently. It examines issues related to the emergence of certain kinds of "hyper" masculinity in situations of conflict and how such masculinities continue to function in subsequent peace-building attempts. This Article argues that a failure to account for and be cognizant of these specific masculinities has a significant effect for women in particular and, more generally, on the success of the conflict transition process. Finally, we show how using a gender lens could make a difference by considering the specific example of the impact of violent masculinities on disarmament, demobilization, and reintegration programs.
\end{abstract}

\section{INTRODUCTION}

The newspapers are filled with information about countries

* Naomi Cahn is the John Theodore Fey Research Professor of Law, George Washington University Law School.

** Fionnuala Ní Aoláin is the Dorsey \& Whitney Chair in Law, University of Minnesota Law School and Professor of Law and Co-Director Transitional Justice Institute, University of Ulster. We thank New England School of Law for the opportunity to deliver this lecture, which honors the memories of Anna Hirsch and Mary Jo Frug, and we thank Martha Fineman for all of her support on this project.

\section{Acknowledgments}

This Article is derived from a forthcoming book on gender and post-conflict reconstruction, tentatively titled On the Frontlines: Gender, War and the Post-Conflict Process (forthcoming 2010), and co-authored with Dina Francesca Haynes, Associate Professor Law, New England School of Law. 
undergoing transition from conflict to post-conflict status with the assistance of the international community. Importantly such a transition is not always a move from war to peace-recall Afghanistan, the Congo, Iraq, or arguably Sudan-but instead, from conflict to less conflict. In this Article we seek to explore the role that gender plays in the construction and implementation of the post-conflict transitional process. We focus on examining the gendered dimensions of societies emerging from extreme, systematic and institutional violence by multiple parties. Our questions in regard to all of these countries, in all of these varying transition processes, is what we term "the gender question." Where are women to be seen, and how are they visible within the processes that define and shape the cessation of communal violence? How should peace processes approach the forms of masculinity that dominate in situations of endemic violence? How should peace processes address the emergence of "hyper" masculinity in such contexts? What does the absence of gender signify, and how does such absence affect the substance of any particular agreement (whether local or international) to end violence? How does the failure to properly ask and answer "the gender question" undermine the short, medium, and longterm reconstruction of post-conflict societies?

In this Article, we first explore how conflict affects men and women differently, and introduce the gender lens that we use throughout our analysis. We then examine issues related to the emergence of certain kinds of "hyper" masculinity in situations of conflict and in subsequent peacebuilding attempts. Next, we argue that a failure to account for and be cognizant of these specific masculinities has a significant effect for women in particular, as well as the success of the conflict transition process. Finally, we show the critically significant impact of a gender lens by considering the effect of violent masculinities on disarmament, demobilization, and reintegration (“DDR”) programs.

\section{Conflict and Gender: Women}

Conflicts fundamentally affect the lives of men, women, and children. Women face gender-specific issues during and after wars that men do not, including pervasive sexual violence, forced impregnation, reproductive violence, sexually transmitted diseases, and forced abortion. Women and their children experience internal displacement and dominate the refugee populations across conflicts. Women are also differentially affected because of their role as the primary caretaker of the household and family. In this regard, traditional gender dichotomies may be further entrenched and exacerbated during times of extreme violence.

Surprisingly, the transitions born of conflict may yield positive social, economic, and political changes for women. For example, during some conflicts in which aspects of a functioning state and economy continue to 
exist, women can take on roles as workers and laborers outside of the home, opportunities which would never be available were the society not in conflict. Rosie the Riveter, the archetypal woman who was employed in the Second World War to help with the military effort and subsequently transformed the war experience into economic opportunity in the post-war period for women, exemplifies a well-known American illustration of this phenomenon. ${ }^{1}$ In this way, conflict can open up intended and unintended spaces for empowering women, "effecting structural and social transformations and producing new social, economic and political realities that redefine gender and caste hierarchies." ${ }^{2}$

Despite these potentially positive aspects, in most contexts the result of conflict for most women is a negative sum. Economies stall during and after conflict or operate in black and grey markets where women are the least often employed or employable because of their legally enforced second-class status. Across most post-conflict transitions, women are the first to be fired and the last to be hired with the large exception of the false (and temporary) economy built up around the presence of the international community, in which women are paid to fill the "camp follower" positions as housekeepers, cooks, administrators and, of course, for sex. Women and children also constitute the overwhelming number of refugees, and of people displaced from their home communities. The very fact of war can contribute to undermining the limited social stability and security of women in many societies, which is the precursor to any exertion of economic or social autonomy.

We stress that women's roles cannot be essentialized, even in the context of war. Women are frequently violent actors themselves in violent and conflicted societies, both in undertaking primary acts of violence and lending substantial support to men who carry out such actions. Importantly, recognizing that women can be violent has practical consequences. For example, it provides the means to acknowledge that women who have also been combatants face an array of social and cultural challenges that simply never arise for men during and after war. Accepting and accommodating a

1. Family law and feminist scholars have noted that the post-war opportunities came with a later backlash in the 1950s with a renewed conservatism about the role of women in society and a return to fixed roles in a way that reversed many of the earlier advancements. See generally Elaine TYler MAY, HoMEWARD Bound: AMERICAN FAMILIES IN THE COLD WAR ERA 49-80 (1999); Laura McEnaney, Atomic Age Motherhood: Maternalism and Militarism in the 1950s, in Women's AMERICA: REFOCUSING THE PAST 448 (Linda K. Kerber \& Jane Sherron De Hart eds., 5th ed. 2000).

2. Rita Manchanda, Ambivalent Gains in South Asian Conflicts, in The Aftermath: Women In Post-Conflict Transformation 99 (Sheila Meintjes et al., eds., 2001) (citing VeEna Das, Critical Events: An Anthropological Perspective on Contemporary INDIA (2000)). 
more diverse range of roles for women both in war and post-war facilitates a greater conceptual and practical understanding of the lived intersectionalities of most women's lives. Equally, a practice of gendering our analysis of violence thus "cannot be conceptualized without understanding the process of knowledge production as such epistemic practices intersect with the specific prevailing cultural and political conditions." ${ }^{3}$ In reality however, these diverse and highly gendered patterns are rarely identified as co-existing simultaneously for women and not factored into peacemaking agreements and transitional structures. ${ }^{4}$

\section{Conflict and Gender: Men}

A fairly substantial amount of literature has been generated over the years regarding the forms of masculinity that emerge in times of armed conflict and war. ${ }^{5}$ Theorists have identified an organic link between patriarchy, its contemporary outworkings and various forms of masculinity as they arise within societies and institutions. A preponderance of literature across disciplines has deepened our understanding of how masculinities are constructed and differentiated. ${ }^{6}$ While war literature across many disciplines has made significant conceptual and practical use of the term "masculinity," the concept has been less applied and understood to be relevant in the post-conflict context. We argue that masculinities study is a diverse and burgeoning field, which has significant insights to offer to the analysis we wish to advance here. ${ }^{7}$

Masculinity theorists and feminist analysis have not always worked in tandem, and it is only relatively recently that feminist scholars have sought to address what masculinity studies has to offer feminist theorizing. ${ }^{8}$ In this vein, we start by asking the "man" question, interrogating where and how men are situated in relation to the creation, perpetration, and institutionalization of violence. In what ways does hegemonic masculinity

3. Nadera Shalhoub-Kevorkian, Militarization and Violence Against Women IN CONFLiCt Zones In THE MidDle EAST 65 (2009).

4. In this context Shalhoub-Kevorkian uses the concept of "frontliners;" women who occupy parallel and sometimes conflicting roles in violent societies. They are both constrained by highly patriarchal systems but, as a result of the limitations placed on men, have access to and agency within the public sphere. See id. at 4-5, 62-67, 96-97.

5. See generally Joshua S. GoldStein, WAR AND GENDER: How GENDER SHAPES THE WAR System AND Vice Versa (2001); Nira YuVAL-Davis, Gender and NATION (1997).

6. See, e.g., Nancy J. Chodorow, Femininities, Masculinities, Sexualities: Freud And Beyond (1994); R.W. Connell, Gender And Power: Society, the Person, AND SeXual Politics (1987).

7. See, e.g., Connell, supra note 6; Michael S. Kimmel, Manhood in AMERiCA: A CUltural History (2005).

8. See, e.g., NANCy E. Dowd, RedEFINING FATHERHOOD (2000). 
work, and how do masculinities operate to benefit even those men who are at the margins of masculinity norms and practice? Somewhat ironically, even within the hierarchies of masculinity, subordinated masculinities can benefit from the social construction of male privilege and value.

While an enormous amount of scholarship has been generated about the varying forms of masculinity and their effects, of particular interest to our analysis is the lens of "hyper" masculinity. In our emphasis on hypermasculinity, we draw on Angela Harris' definition of "a masculinity in which the strictures against femininity and homosexuality are especially intense and in which physical strength and aggressiveness are paramount." ${ }^{\text {"9 }}$ We frame our analysis by affirming that other kinds of masculinities coexist with hypermasculinity, but notably in situations of conflict and endemic violence, hypermasculinity plays an enlarged and elevated role. Its social traction is intensified when violence is endemic, and other social strictures are slackened, and the unloosening of these patterns and hierarchies is particularly fraught in the post-conflict process.

One clear parallel for non-conflicted states is to analogize the emergence of hypermasculinity with the role of the military in multiple cultures and societies. The military is closely tied with manhood, and, indeed, militaristic actions are supported by an ideology of male toughness. ${ }^{10}$ Self-evidently, men dominate most national and international militaries. By the time the conflict ends, men who have acted militarily and the (generally) male political elite are deeply enmeshed in this cultural vision of manhood. As former combatants in Colombia explained to anthropologist Kimberly Theidon, for example, joining a paramilitary group allowed the men "to 'feel like a big man in the streets of their barrios,' to 'go out with the prettiest young women,' and to 'dress well,' privileges they insist would not have been possible if they weren't carrying a gun." 11 We suggest that the prevalence of this kind of masculinity poses complex issues for undoing violence, for mainstreaming gender equality and for remaking societies that have been fractured and deeply divided.

Post-conflict societies present a unique and under-analyzed site of examination for masculinities. One of the main reasons for the lack of attention to masculinities in this domain is the presumption that the postconflict context is equated to peace and that the absence of war makes moot any analysis of masculinity, which may be presumed "tamed" by the end of

9. Angela P. Harris, Gender, Violence, Race, and Criminal Justice, 52 STAN. L. REV. 777, 793 (2000).

10. See Goldstein, supra note 5, at 5-6; see also Kimberly Theidon, Transitional Subjects: The Disarmament, Demobilization and Reintegration of Former Combatants in Colombia, 1 InT'L J. Transitional Just. 66, 76 (2007).

11. Theidon, supra note 10 , at 76. 
violent contestation. This presumption fails to account for the ways in which women experience violence both in conflicted and post-conflict societies. The result of this lack of attention to masculinities means a failure to account for the myriad of ways in which masculinities transform, adapt and reformulate in the post-conflict environment. Consequently, close attention to the forms and impact of masculinities in the post-conflict milieu is critical not only for women's experiences in the process, but also for the success of the transition itself.

Indeed, the post-conflict environment, like conflict, is also "vividly about male power systems, struggles and identity formation." 12 There may be an enormous flux in the male post-conflict fraternity both on an individual and communal level. Moreover, international organizations and institutions, typically headed by male elites, are arriving to reconfigure the transitioning society. So, men who were in power are losing power, other men (domestic and international) are taking their place, and as is often the case when a conflict stalemate arises, internationals (generally culturally and politically differentiated other males) are coming into a society to fill a vacuum.

One enduring question that emerges from the conflict and masculinities literature is why men engage in violence? Without over digressing, we point out that violence, as an aspect of masculinity, is deeply linked to the assertion of social status and the value of self in particular contexts. Violence may literally "make the man" in many societies, and not infrequently the site of the violence is the woman's body. In recognizing such deeply rooted links between the constructions of the masculine self, and the social acceptance of "manhood," we acknowledge the difficulties that arise as we address the end of violence (as a formal legal matter). The end of violence is not a superficial engagement, but may require deep and difficult entanglement with the masculine construction of self in many societies. In post-conflict societies, such conundrums are compounded by the lack of other opportunities available to men to assert positive masculinities, and to have practical and symbolic roles within societies that struggle on the economic margins and are deeply politically dysfunctional.

This question of violence and its ending is central to the post-conflict experience because the cessation of public violence between (generally) male combatants is usually the litmus test by which the success of transition from war to peace is measured. We take issue with the presumption that the end of public violence and the measurement of security based on the safety of male combatants should constitute an adequate calculation of peace in any society. While analysis of the

12. Lori Handrahan, Conflict, Gender, Ethnicity and Post-Conflict Reconstruction, 35 SECURITY DiALOGUE 429, 433 (2004). 
causality of violence is central to addressing transformation in the postconflict environment holistically, issues of causality are extremely complex, dependent on variations in social and cultural contexts. The analysis is also made more complicated by a deeper recognition of the role that masculinities play in giving rise to violence, and the difficulties of transforming such practices on a fundamental level. Nonetheless, greater attention to causality is entirely relevant to addressing women's experience of violence as well as implementing measures in post-conflict societies that meaningfully address the need for women's security.

The causes of violence and conflict in a range of societies are far too complex to explore here. ${ }^{13}$ But a number of cluster causalities are useful to identify: first, economic and social insecurity; second, a lack of legal and political status particularly associated with group or ethnic identity; and third, the lack of opportunity for meaningful self-determination (whether external or internal) within the state. In multiple contexts, engaging in violence is a rational choice for men when few other opportunities may be provided to gain economic security (albeit that participation in violence provides a highly tenuous economic existence or longevity), social status and value within their communities, and security (again albeit tenuous and fragile) for their families and communities. As post-conflict literature has begun to explore, there is a strong overlap between all these causal categories and the emergence of certain forms of masculinity in conflicted societies. Without addressing the causalities outlined above within a framework that integrates masculinities, we may also fail to address the ongoing realities of how masculinities closely interconnect with postconflict social, political, and economic outcomes.

Beyond a more nuanced recognition of international masculinities, we also want to address a more complex set of role assumptions for men and women in post-conflict societies. This requires asking the fundamental question of what does it mean "to be a man" in a violent society, when violence begets status and economic capacity? Even more relevant to our inquiry, what happens to such masculinities when societies transition from violence and move towards democratic or more liberal forms of political engagement? Which men lose and gain in such contexts? As both Brandon Hamber and Amy Maguire have explored in post-apartheid South Africa and transitionary Lebanon, women often bear the brunt of the flux in masculine roles. ${ }^{14}$ The theoretical gains made by women in status and legal

13. See generally Christian P. Scherrer, GenOCide AND CRisis in CENTRAl Africa: CONFlict RoOts, Mass Violence AND Regional WAR (2002).

14. See Brandon Hamber, "We Must Be Careful how We Emancipate Our WOMEN": Shifting MAsculinities IN Post-Apartheid South AFrica 22-24, 26 (2006), http://www.brandonhamber.com/publications/Paper\%20Careful\%20how\%20we\%20emanci pate.pdf; Amy Maguire, 'Security Starts with the Law': The Role of International Law in the 
protection are much more complex in reality. One female participant in a study of women's experiences of post-conflict security in South Africa has noted:

I think, in as much as the law of the country allows women to be empowered, that is going to have a spin-off effect on men's behaviour and men's attitudes towards women. In particular, those so-called empowered women. They'll always be the subject of abuse ... everywhere you go ... if you are perceived to be an empowered woman you are subject to a lot of abuse from society in general. ${ }^{15}$

The link between formal (generally equality) gains made by women in many post-conflict legislative and constitutional enactments, conjoined with the political displacement of power for many men from the traditional routes provided during armed conflict, creates a complex social and legal terrain. It is upon this territory that women's gains and their intersection with masculinities in flux are played out. Formal gains for women may, in fact, be nullified or significantly constrained by the reality of social and community context, in which the accommodation of men's deeply entrenched social status may outweigh the enforcement of formal legal norms in practice. ${ }^{16}$ Moreover, the social realities that women confront in highly patriarchal societies are propped up and perpetuated by masculinities in action - limiting in subtle and crosscutting ways the reach of law.

It is also vital to contextualize the reality of economic fragility faced in post-conflict zones around the world. Countries emerging from conflict are some of the poorest on the planet. ${ }^{17}$ They have the highest number of refugee populations (who are predominantly female with child dependents) and internally displaced persons. ${ }^{18}$ In this context, when one domain of

Protection of Women's Security Post-Conflict, in THE Role of InTERnATIONAL LAW IN Rebuilding Societies After Conflict: Great ExPeCtations 226 (Brett Bowden et al. eds., 2009).

15. Maguire, supra note 14, at 226.

16. For an analysis of this dynamic in the context of reparations in transitional societies see Ruth Rubio-Marin, The Gender of Reparations in Transitional Societies, in THE GENDER of Reparations - Unsettling Sexual Hierarchies While Redressing Human Rights Violations 63 (Ruth Rubio-Marin ed., 2009).

17. As of 2008, Somalia's GDP per capita was \$600; Rwanda’s GDP per capita was \$1000; Burundi's GDP per capita was \$400; and Columbia's GDP per capita was $\$ 8800$. See CIA, THE WORLD FACTBOOK, https://www.cia.gov/library/publications/the-worldfactbook/region/region_afr.html (select a specific country from the drop-down menu; then select economy).

18. As of January 2009, Rwanda had 55,062 refugees; Somalia had 1,842 refugees and 1,277,200 internally displaced persons; Burundi had 21,093 refugees and 100,000 internally 
status and economic subsistence is closed off (by the end of violent armed conflict) such societies struggle to replace the dysfunctional economy of war with a functional liberal economy of provision. The tools that for some men provided a means of survival in war are unreliable and may no longer be needed. Men and young boys who are under or uneducated are at a considerable and material disadvantage in such settings. In this space of economic struggle, Gary Barker and Christine Ricardo illustrate the rise in the parallel economics of criminality and "normal" violence, which allow certain forms of masculinity to endure and provide both status and material needs. ${ }^{19}$ They note the particular difficulties of confronting violent masculinities in social settings that have operated to seal off men spatially from women and children. This is further compounded in societies that have deeply stratified gender roles, leaving little room for the expression of positive masculinities in either the public or private sphere. The effects of such stratification are also intensified when one accounts for intergenerational transmission of violent norms, as well as in societies where age stratification is intense, creating intense competition for economic and sexual resources as well as opportunities. ${ }^{20}$

\section{The Gender Lens}

Having explored how conflict affects both men and women, we want to affirm the importance of a gender lens and investigate its impact. The independent value of a gendered assessment of post-conflict processes remains contested. In the legal and political space of ending or transmuting conflict, women still struggle to assert the magnitude of issues that affect them directly. They remain subordinated by dominant discourses that minimize or ignore the value of placing the needs and views of women at the center of the conversation about ending violent communal behaviors, even though such placement is absolutely central to ending societal violence. It needs constant restatement that women are the group most historically marginalized and excluded from the peacemaking and peace-

displaced persons; and Columbia had 170 refugees and 3,000,000 internally displaced persons. See UNHCR, The UN Refugee Agency, http://www.unhcr.org (select the specific country under "browse by country" to view the "Statistical Snapshot") (last visited Dec. 3, 2009).

19. Gary Barker \& Christine Ricardo, Young Men and the Construction of Masculinity in Sub-Saharan Africa: Implications for HIV/AIDS, Conflict, and Violence, in SOCIAL Development Papers: Conflict Prevention \& Reconstruction, Paper No. 26, at 31-32 (also published as Social Development Paper No. 84, 2005), available at http://wwwwds.worldbank.org/external/default/WDSContentServer/WDSP/IB/2005/06/23/000012009_ 20050623134235/Rendered/PDF/327120rev0PAPER0AFR0young0men0WP26.pdf.

20. Id. at 12. The limits on access to land in sub-Saharan Africa are pivotal for the transmission of social status, marriage opportunity, and independence for young men. 
[Vol. 44:nnn

building processes across all jurisdictions and conflicts. ${ }^{21}$ Applying the gender lens is critical to ensuring the effectiveness of policies and practices involved in ending conflicts and ensuring that they do not recur. Without this attention, traditional gender dichotomies may be further entrenched and exacerbated during times of extreme violence and extended in the postconflict phase.

While women are missing from key roles in peace negotiations and government, they often dominate in civil society movements that create "safe" and neutral spaces in conflicted societies. In this latter role, women often provide the grassroots networking and social support structures that are relied upon by local and international elites to embed peace processes. But this raises of the issue of whether those involved in the reconstruction process essentialize women by reducing and collapsing their varied roles into a single dimension that relegates them to "soft" civil society roles, rather than tangible roles entrenched in the political infrastructure. We remain consistently wary of essentializing women as peacemakers and facilitators when we are deeply aware of the complex set of roles women as individuals and as members of broader communities play in enabling and encouraging violence. Such essentialization also underplays the extent to which women play an under-appreciated role in supporting and enabling certain kinds of masculinities to thrive.

Using the gender lens helps us understand that gender must become central to conflict resolution, peace-keeping, reconstruction, and reconciliation efforts. Integrating gender into the post-conflict process is insufficient unless gender is incorporated into all aspects and levels of the newly developing or rehabilitating state. For gender to be absolutely involved it must be addressed in every issue and at every level. In this view, it is insufficient for formal legal norms alone to confront the inequalities, violence and discrimination that women may have experienced during conflict, or for women to have an impact solely through civil society. Rather, a broadly framed set of imperatives is required which includes legal reform to address harm and exclusion and also takes account of the broader psycho-social and customary practices identified earlier in our analysis of masculinity in action. For example, gender inclusion has often focused almost exclusively on holding war crimes perpetrators accountable for sexual violence. We cannot, however, evaluate the credibility and value of such accountability mechanisms without an eye to the broader transitional and gendered dynamic of the society in question. ${ }^{22}$

21. On peace agreements generally, see Christine Bell, Peace AgreEments And HUMAN RigHTS (2000).

22. For further discussion see CAHN ET AL., ON THE FrONTLINES: GENDER, WAR AND THE POST-CONFLICT PROCESs (forthcoming 2010). 
Moreover, we cannot hope to dislodge practices of violence towards women (before, during and after conflict) unless we are prepared for a hard interface with the social embeddings of violence in the individual identities and social practices of men.

In its broader context, our approach challenges conventional notions concerning the role, and rule, of law in post-conflict situations. For those of us trained to think in terms of legal solutions; of justice via international, regional, or local tribunals; of prosecutions and investigations; and evidence and trials, these concepts must be tested in countries with a minimally functioning justice system, with no means of protecting victimwitnesses, and with only minimal assurance that genocide and genderbased violence will not recur. In these countries, we must be particularly sensitive to what role the law can and should play in ending impunity and restoring confidence that the war wounds can be healed. An emphasis on the relationship between masculinities and violence in conflicted and postconflict societies permits us to identify a much broader array of enabling phenomena resulting in women's experiences of systematic violence. In doing so, we become acutely aware that formal legal mechanisms provide only part of the solution.

Finding justice for victims and punishing perpetrators is critical, but there are important contextual issues on how best to proceed to ensure that accountability occurs as countries struggle to establish new governments. In our focus on legal approaches, we must remember the practical realities that confront victims of gender-based violence as they continue with their lives, often living in the same communities as the perpetrators, and thus craft remedies that account for these differing, potentially conflicting, realities which themselves may reflect divergent constituencies: a need for punishment; a need for rehabilitation for both victims and perpetrators; and a need for moving on politically in a divided society.

IV. Sites of Masculinity Struggle in the Post-Conflict EnvironmentDisarmament, Demilitarization, and Reintegration

To show how a gender lens might matter, we turn to the process of Disarmament, Demilitarization, and Reintegration (DDR). DDR efforts are integral parts of peace-making and development processes in multiple conflict situations. ${ }^{23}$ An extensive general literature has emerged on the

23. A strong link has been established between disarmament and development. See generally David A. Koplow \& Philip G. Schrag, Carrying a Big Carrot: Linking Multilateral Disarmament and Development Assistance, 91 Colum. L. REv. 993, 1026-42 (1991); Herbert Wulf, Disarmament as a Chance for Human Development: Is There a Peace Dividend? (UNDP, Occasional Paper No. 5, 1992), http://hdr.undp.org/en/reports/ global/hdr1992/papers/herbert_wulf.pdf. 
subject of DDR, ${ }^{24}$ as well as more particular case-study analyses, looking at particular countries and how they have reintegrated and demobilized (or not) former combatants. ${ }^{25}$ DDR comes with strong instrumental and policy goals. At its essence it may function as the most important preliminary step in ending or limiting violent conflict. It can act instrumentally to facilitate control over armed forces (both state and non-state). Less obviously, DDR can create extraordinary vulnerabilities in societies where guns are "both a threat and a source of security." ${ }^{26}$ Thus, addressing the full spectrum of gendered issues for men and women is a complex and highly variable task. The demobilization, demilitarization and reintegration, (with equal emphasis on all three elements) of former combatants clearly overlap with the production, control, and maintenance of masculinities in conflicted and post-conflict societies.

DDR programs do not follow one template, but they are typically discussed during the peace process and established after the peace accord

24. See, e.g., U.N. Dep't of Peacekeeping Operations [UNDPKO], Lessons Learned Unit, Disarmament, Demobilization and Reintegration of Ex-combatants in a Peacekeeping Environment: Principles and Guidelines (2000), available at http://www.reliefweb.int/ rw/lib.nsf/db900sid/LGEL-5SJHQ2/\$file/dpko-ex-comb-dec99.pdf?openelement; Mats R. Berdal, Disarmament and Demobilisation after Civil Wars: Arms, Soldiers and the Termination of Armed Conflicts, in ADELPHI PAPER 303, at 9, 73-76 (Int'l Inst. for Strategic Stud., 1996); Kimberly MAhling Clark, Fostering a FAREWEll to ARMs: PRELIMINARY LESSONS LEARNED IN THE DEMOBILIZATION AND REINTEGRATION OF COMBATANTS (USAID 1996), available at http://pdf.dec.org/pdf_docs /pnaby027.pdf; Lotta Hagman \& Zoe Nielsen, A Framework for Lasting Disarmament, Demobilisation, and Reintegration of Former Combatants in Crisis Situations, in IPA WORKSHOP REP. (Int'l Peace Acad., Report of Dec. 12-13 Workshop, 2002), available at http://www.ipacademy.org/media/pdf/publications/framework_for_ddr.pdf; KEES KINGMA,

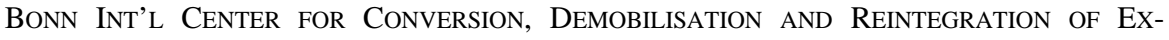
combatants in Post-war And Transition Countries: Trends and Challenges of EXTERNAL SUPPORT passim (2001), available at http://www.bicc.de/uploads/pdf/ publications/other/gtz_studien/demob/demobilisation.pdf; Mark Knight \& Alpaslan Özerdem, Guns, Camps and Cash: Disarmament, Demobilization and Reinsertion of Former Combatants in Transitions from War to Peace, 41 J. PeACE Res. 499 (2004).

25. See, e.g., Kris Brown \& Corinna Hauswedell, Burying the Hatchet: The Decommissioning of Paramilitary Arms in Northern Ireland, in INITIATIVE ON CONFLICT Resolution AND Ethnicity 22 (Bonn Int'l Ctr. for Conversion, Brief No. 22, 2002); Markus Koth, To End a War: Demobilization and Reintegration of Paramilitaries in Colombia, in BONN INT'L CTR. FOR CONVERSION: PAPER 43, at 5 (2005); Christopher Alden, Making Old Soldiers Fade Away: Lessons from the Reintegration of Demobilized Soldiers in Mozambique, 33 Security Dialogue 341 (2002); Jessica Schafer, 'A Baby Who Does Not Cry Will Not Be Suckled': AMODEG and the Reintegration of Demobilised Soldiers, 24 J. S. AFR. STUD. 207, 208 (1998).

26. Kimberly Theidon, Reconstructing Masculinities: The Disarmament, Demobilization and Reintegration of Former Combatants in Colombia, 31 HuM. RTS. Q. 1, 19 (2009). 
has been signed, as one of the first components of implementation. ${ }^{27}$ Recall that women are significantly absent or excluded from the peace-making process. Moreover, even where women are present at peace negotiations, the specific negotiation sites in which demilitarization and security are agreed tend to be exclusively male and lack gender parity in representation, going hand in hand with the reality of women's lack of high-level status in the military and/or at the commander level of non-state paramilitary forces. ${ }^{28}$ Examples of the integration of demilitarization with the formal peace deal include the Good Friday Peace Agreement in Northern Ireland, various versions of the Colombian peace process and the demilitarization of former combatants in Mozambique. It is generally agreed that DDR programs should only be undertaken with certain conditions present, such as a peace accord that establishes the framework for DDR, a general sense of confidence in the peace process itself; minimal and meaningful levels of security, ownership of DDR by all relevant stakeholders; and basic guarantees of information and transparency. ${ }^{29}$ Given the fractured nature, form, and implementation of peace agreements, however, this rarely happens.

Traditional or "classical” DDR programs, which assume ideal—and rare-conditions, conceive of DDR as a set of technical interventions to assure, for example, effective containment of armed groups, collection and destruction of weapons, division of former combatants into those who will remain in or join the country's armed forces and those to be demobilized, and then the effective reinsertion, reintegration, and rehabilitation of those demobilized into their communities of origin. ${ }^{30}$ The obvious point of course is that there is a variance of emphasis across most DDR implementations, but a general pattern is that demobilization gains considerable and quick traction while the reintegration and rehabilitation portion draws much less reflection, funding, and applied enforcement from the state and the

27. See UNDPKO, supra note 24, ๆף 10, 12; Berdal, supra note 24, at 9, 73-76; ClARK, supra note 24; Hagman \& Nielsen, supra note 24, at 1; KINGMA \& BONN INT’L CTR. FOR CONVERSION, supra note 24; Koth, supra note 25, at 25-26; Knight \& Özerdem, supra note 24, passim.

28. See Fionnuala Ní Aoláin, Women, Security and the Patriarchy of Internationalized Transitional Justice, 31 Hum. RTs. Q. 1055, 1080-82 (2009).

29. Jason Aplon, Acting Deputy Dir., Office of Dep't Transition Initiatives, Agency for Int'l Dev., U.S. Dep't of State, Presentation at the Program on States and Security at the Ralph Bunche Institute for International Studies: Post-Conflict Peacebuilding: Connecting Research and Policy (Jan. 25, 2008). See NiCOle Ball \& LuC VAn DE Goor, Disarmament, Demobilization AND Reintegration: MAPping Issues, Dilemmas AND Guiding PRINCIPLES 5-6 (2006), http://www.reliefweb.int/rw/lib.nsf/db900sid/HVAN-6UFKQR/ \$file/cling-ddr-aug2006.pdf?openelement.

30. See Lisa J. Laplante \& Kimberly Theidon, Transitional Justice in Times of Conflict: Colombia’s Ley de Justicia y Paz, 28 Mich. J. InT’L L. 49, 57-58 (2006). 
international community. DDR requires some minimal levels of security as a baseline for establishing the institutional structure for disarmament and for making former combatants feel safe in relinquishing their weapons. It also requires that all parties, including the former combatants and new government as well as international actors, commit to its implementation with consensus as to the basic outline of the process. ${ }^{31}$

The most intensive operations occur post-stabilization, during the transition and recovery period. ${ }^{32}$ The actual implementation often starts with combatants voluntarily entering reception centers turning in weapons to begin the demilitarization process. ${ }^{33}$ Such programs are typically administered by a multilateral organization and/or the United Nations, and the World Bank and the United Nations are significant financial contributors. ${ }^{34}$ These programs, world-wide, cost more than $\$ 1.5$ billion per year, and they generally occur in some of the poorest countries. ${ }^{35}$ Because DDR processes depend on broader developments towards a peaceful environment, they are subject to frequent disruptions, and they seldom proceed in a linear fashion. ${ }^{36}$

The existence of DDR raises complex questions in post-conflict or regime change societies from a gender perspective. For example, disarmament has a high crossover with political decisions and compromises involving amnesty for human rights and humanitarian law violations, including amnesty for crimes involving sexual violence or violence against women. ${ }^{37}$ In contexts where women are the least likely to be present at the

31. See BALL \& VAN DE GoOR, supra note 29, at 5-6.

32. Integrated Disarmament, Demobilization and Reintegration Standard, 2.20 Postconflict Stabilization, Peace-building and Recovery Frameworks, 5-7 (2006), available at http://www.unddr.org/iddrs/02/download/IDDRS_220.pdf.

33. See, e.g., Susan McKay \& Dyan Mazurana, Where Are the Girls? Girls in Fighting Forces in Northern Uganda, Sierra Leone, and Mozambique: Their Lives DURING AND AFTER WAR 98 (2004).

34. See, e.g., United Nations Office for Disarmament Affairs, http://www.un.org/ disarmament/HomePage/about_us/aboutus.shtml; Escola de Cultura de Pau, DDR 2009: Analysis of Disarmament, Demobilisation and Reintegration (DDR) Programmes in the World During 2008 (2009), available at http://escolapau.uab.cat/img/programas/desarme /ddr/ddr2009e.pdf.

35. See U.N. Disarmament, Demobilization and Reintegration Resource Centre [UNDDRRC], Country Programmes, http://www.unddr.org/countryprogrammes.php (select desired country; then follow "funding” hyperlink) (last visited Nov. 30, 2009).

36. See BALl \& VAN DE GOOR, supra note 29, at 11.

37. For example, Section 8 of the Belfast, or "Good Friday" Agreement in Northern Ireland deals with security, referring to the "normalisation" of security arrangements and practices. This is to include the reduction of armed forces, the removal of security installations and emergency powers, and other measures appropriate to and compatible with a normal peaceful society. Northern Ireland Office, The Agreement, available at 
negotiation, deals are struck that include amnesty for crimes involving sexual violation, mutilation, reproductive harms, the transmission of sexually transmitted diseases and HIV/AIDS and forced impregnation. ${ }^{38}$ The amnesty is often the precursor to the DDR program, and given that gendered harms may not be viewed as necessarily threatening the growing international consensus that certain crimes against humanity cannot be subject to amnesty, ${ }^{39}$ the gendered fault line may simply not be noticed or assessed as a fundamental bias to such processes. This challenging nexus between gender and disarmament is important to highlight. Political compromises, including amnesty for serious human rights violations that have occurred during a conflict, mostly made by elite men, often fail to engage with the particular vulnerabilities created for women by partial or excluded accountability.

Gender perspectives are important to DDR for numerous reasons. First, armed conflict affects women and men differently, and that difference is seldom taken into account in designing and implementing DDR programs. The obvious point being that women are often hugely affected in their day-to-day lives by the way in which a DDR program is implemented. The range of effects include the front line exclusions that fail to accommodate women in compensation schemes and the internal effects which may include the return of violent men to their communities with little if any recognition of the potential harms that they may visit on their home environments, and little if any support to victims when subsequent harms occur. Second, under many existing programs, women and men have unequal access to resources following conflict. Particularly in light of the gender bias and inequalities that underpin many societies, DDR may focus only on male combatants. What this means in practice is that the economic benefits that flow from DDR will rarely flow to women (even when they have been combatants in the traditional sense), and the distortion of the post-conflict economy can be linked to DDR payments. Third, achieving peace requires the inclusion of all members of society, male and female, and it is a long-term process. Peace remains elusive after civil wars in most post-conflict situations. Though DDR may be conceived as the means to deliver conflict endings in the short term, we caution that inadequate or poorly managed DDR programs may in fact create further cycles of instability in a post-conflict society, leading inexorably to the perpetration

www.nio.gov.uk/the-agreement (follow “Agreement” hyperlink to read the full text of the Agreement) (last visited Nov. 12, 2009).

38. See The Transitional Justice Institute, Peace Agreement Database (2008), http://www.transitionaljustice.ulster.ac.uk/peace_agreements_database.html (select "enter database;" then fill out the search criteria).

39. See generally Amnesty, Human Rights and Political Transitions: Bridging THE PEACE AND Justice Divide (2008). 
of further communal violence. Finally, adding a gender analysis requires focusing specifically on men and issues of masculinity. ${ }^{40}$ By this we mean that close attention must be paid to the psychosocial dimensions that create and elevate the emergence of certain kinds of masculinity in society and rewards those men who exhibit these characteristics. Attention to this dimension requires valuing gender equality as a core dimension of the DDR process and preparing to posit the success of these programs on the extent to which they actually operate to bring about a lessening of overall violence in a society (in both private and public spheres) as well as in handing over arms. We acknowledge, of course, that for DDR interventions to succeed, they must be designed in the context of each country's special circumstances, and consistently deploy gender as a centralizing mechanism.

Accordingly, using a gender perspective leads to a series of additional issues concerning the structure of DDR programs. First, what constitutes disarmament sufficient to satisfy a ceasefire requirement in the political/military sense may not in fact entail the removal of all such weapons from the public and, more importantly, the private sphere. ${ }^{41}$ An obvious linking issue is how to measure the success or failure of demobilization from a gender perspective. ${ }^{42}$ This benchmarking for success through a gender-sensitive lens is markedly absent through many of the programs that are heralded as success stories by the international community. Second, demobilization generally fails to address the deep imprinting of violent masculinities in former combatants and the effects of a militaristic culture on the civilians that surround him in the transitional

40. See U.N. Dept. for Disarmament Affairs in collaboration with the Office of the Special Adviser on Gender Issues and the Advancement of Women, Gender Perspectives on Disarmament, Demobilization, and Reintegration (DDR) (March 2001), http://www.un.org/ disarmament/HomePage/gender/docs/note4.pdf; Theidon, supra note 26. Brandon Hamber emphasizes the importance of not essentializing men, while recognizing the importance of studying masculinities. Brandon Hamber, Masculinity and Transitional Justice: An Exploratory Essay, 1 InT’L. J. TRANSITIONAL JUST. 375 (2007).

41. Specifically, according to the UNDP, there are some 550 million small arms circulating in the world today. See United Nations, Human Dev. Report 2002, at 97 (2002). Only forty-one percent of these weapons are in the hands of the regular armed forces. See Press Release, Hans Winkler, State Sec'y, Austrian Federal Ministry for Foreign Affairs, Conflicts Cannot be Resolved Using Arms (June 26, 2006), available at http://eu2006. gv.at/en/News/Press_Releases/June/2606WinklerUN.html. Many women express “deep disappointment in the disarmament process.” Human Rights WATCH, BETwEEN Hope AND Fear: Intimidation and Attacks Against Women in Public Life in Afghanistan 4 (2004). For example, security threats have impeded women's ability to travel, study, and work in post-Taliban Afghanistan. Id. at 2.

42. Methods for evaluating DDR from a gender perspective are explored further in CAHN ET AL., supra note 22. 
and post-conflict context. $^{43}$ The underlying social-psychological dimensions which, in a conflicted society, have supported the resort to violence and the elevation of particular forms of masculinity that accompany it, are not in any sense undermined or addressed by a formal demobilization process. Thus, a key issue to be addressed concerning violence is what is meant by the term "ending violence." In the parlance of ending public violence or internal conflict, this conversation revolves around decommissioning weapons and getting armed paramilitaries/insurgents to swap violent confrontation for peaceful debate about contested issues. However, this kind of discussion rarely engages with the fundamental requirement of changing deep-seated social attitudes toward the use of violence. ${ }^{44}$ Self-evidently, where discharged-but-notdisarmed combatants return to their homes and families with their weapons, the sites of violence may simply move from the public to the private sphere. $^{45}$

\section{Attention to Masculinities}

As societies transition from violence and move towards democratic or more liberal forms of political engagement, close attention must be paid to masculinities as part of the project of ending violence. Failure to account for and be cognizant of these specific masculinities has significant effects for women, but more generally on the success of the conflict transition processes. DDR programs struggle with "what to do with the 'morass of malignant male muscle' .... . Men unable to positively manifest masculine roles may return to violent and destructive means of expressing their identities." 46 Factoring this psychosocial reality into the design and implementation of DDR programs is a means to avert inevitable structural

43. Notably, addressing masculinities requires paying attention to the ways in which women often actively participate in facilitating and supporting men's militarized masculinity. See Theidon, supra note 26, at 29; see also GoldstEIn, supra note 5, at 306.

44. See, e.g., Amnesty International, The Impact of Guns on Women's Lives (2005), available at http://www.amnesty.org/en/library/info/ACT30/001/2005/en (follow "Download: PDF") (containing a sustained and detailed cross-jurisdictional study of the "ordinary" impact of gun violence against women). The study notes that "although available data supports the widespread assumption that most direct casualties of gun violence are men, particularly young men, women suffer disproportionately from firearms violence, given that they are almost never the buyers, owners or users of such weapons.” Id. at 6 (footnote omitted).

45. Fionnuala Ní Aoláin, Women, Security, and the Patriarchy of Internationalized Transitional Justice, 31 HuM. RTS. Q. 1055 (2009).

46. U.N. Dev. Fund for Women [UNIFEM], Getting it Right, Doing it Right: Gender and Disarmament, Demobilization and Reintegration 19 (2004), available at http://www.iknowpolitics.org/files/Getting_it_Right_Doing_it_Right.pdf. 
barriers to the success of a key element of conflict-ending processes.

Masculinities appear in several different ways throughout the DDR and other processes. First, socialization into male roles as both traditional head of household and then-as a result of the conflict-into the assumption of violent roles may be difficult to undo. The complexity and difficulty of this task should not be underestimated by policy-makers, and it underscores that processes and policies sensitively attuned to the dynamics of embedded socialization will reap both immediate and inter-generational benefits.

The magnitude of this socialization lies with the complexity of managing the forms of violence that emerge in many transitional societies, a context that is acutely illustrated in the relationship between disarmament and intimate violence. As a starting point, underlying endemic sexual and domestic violence is never calculated into an overall accounting for the experience of violence during conflict. There is a strong and maintained presumption that sexual violence in war is a thing apart, an experience capable of being parsed out from the "regular and normal" violence that accompany women's lives in many societies. As feminist international scholars have long noted, sexual and gender-based violence rarely conforms to the timelines of peace treaties and ceasefires but endures past them. The kinds of violence and sexual acts perpetrated upon women in conflicted societies endure as a form of entrenched "othering" in such societies, and pervades the way in which women subsequently experience inequality, discrimination, and exclusion. Many observers and commentators on post-conflict societies have asserted that there is a marked rise in the violence that women experience post-conflict. ${ }^{47}$ Statistics in a number of post-conflict societies that measure such acts suggest, at least, a marked increase in reported violence. ${ }^{48}$ There is, however, still a need for additional empirical evidence to document such an overarching trend, but at the very least, there is room to acknowledge the continued pervasiveness of violence for women when peace is theoretically won. This ongoing violence undoes a pervading premise that women and men experience the post-conflict gains in the same way.

\section{A. Re-Socializing Men}

One of the central quandaries for the DDR process is how to undo the masculinities learned during wartime. Where discharged combatants return to their homes and families, the sites of violence may simply move from

47. See Sheila Meintjes et al., There is No Aftermath for Women, in THE AfTERMATH: Women in Post-Conflict Transformation 3-18 (Sheila Meintjes et al. eds., 2001).

48. See, e.g., Tina Sideris, Rape in War and Peace, in The AfTERMATH: Women in POST-CONFLict TRANSFORMATION, supra note 47, at 153-57. 
the public to the private sphere. From the gendered critique of accountability mechanisms, what we learn is that truth processes may examine the prior violence in the public sphere, but will not engage in any way with the continual violence that is facilitated in the private sphere by non-rehabilitated former combatants. The disconnect between the operation and scope of the transitional justice mechanism and the intimate and everyday realities of living with a former combatant for women could hardly be more starkly contrasted.

This disconnect has been graphically identified in such transitional societies as South Africa. ${ }^{49}$ For example, the perceived escalation of domestic violence rates post-apartheid have raised deep concerns about the relationship between pre-existing apartheid violence and its spill-over to a transitional society. There is some evidence that post-conflict societies do (at least) statistically experience greater proportions of domestic and intimate violence. ${ }^{50}$ Thus, increased reporting at the end of conflict may not mean absolute empirical increases in violence per se; rather, it may simply mean that reporting is possible where it was not previously, and in fact, the forms of violence may be more muted. Nonetheless, while it remains open to further empirical investigation to assess the fullness of the relationship between violence during conflict and increased violence post-conflict, what remains clear is that there is a continuum of violence for women and that the end of conflict is not the end of gendered violence. The normality of ongoing violence for women is itself broadly sustained through political transformations.

The reassertion of violence in the private sphere during the transitional phase may constitute a form of compensation for male combatants, for their loss of public status and hegemony. ${ }^{51}$ This is graphically shown by the psychological phenomena of the returning warrior who has, through conflict, normalized the use of violence and views the home as another site in which to exercise power and control through physical force. ${ }^{52}$

DDR programs can help to separate manhood from its violent and military meaning by providing positive, non-violent role models and means for achieving status. Kimberly Theidon observes that many of the former combatants in Colombia told her they were "tired" of combat; she suggests

49. See supra Part II for further discussion.

50. See Monica Mcwilliams et al., Tackling Domestic Violence: A Policy For NORTHERN IRELAND (1995); see generally supra notes 46-47.

51. See, e.g., Anu Pillay, Violence Against Women in the Aftermath, in THE AFTERMATH: WOMEN IN POST-CONFLICT TRANSFORMATION, supra note 47, at 35-45.

52. See Fionnuala Ní Aoláin \& Catherine Turner, Gender, Truth, and Transition, 16 UCLA WOMEN’s L.J. 229, 252 (2007). 
that "the DDR program [could] make more explicit what these men gain in the transition from combatant to civilian." 53 In the Congo, for example, the DDR program is collecting information on how programs that involve men can dissolve gender stereotypes. ${ }^{54}$ Offering vocational education and creating employment opportunities in both the public and private sectors can serve to channel aggressive energy into more productive uses. ${ }^{55}$ It is also evident that integrating men more positively into their family and parenting responsibilities offers some means to redress the complex roles that men must manage in the post-conflict context. Here, relatively simple moves, such as ensuring that families and children are integrated into the DDR process, can operate as positive transitionary measures to support both men and women and open up spaces for social transformation. Another important and related move is to extend and broaden the categories of combatants for the purposes of DDR programs, ensuring that women who have provided support roles to military or paramilitary forces (as well as women who have been involved in direct hostilities) are included and fully integrated into structured DDR programs. ${ }^{56}$ This would assist both in ensuring that women combatants are not doubly marginalized by their involvement in military and paramilitary organizations, and that the opportunity is provided to affirm the status of women combatants (who frequently languish and suffer the post-conflict stigma of non-conforming gender roles as society returns to "normal") and to include women fully in the benefits that flow materially and otherwise from demilitarization.

Re-socializing men requires integrating the information known about the effects of hyper and other forms of heightened masculinities into the planning and delivery of what are generally internationally constructed and supported DDR programs. It means moving the emphasis away from merely handing over guns to neutral arbitrators and instead integrating psychological and reflective counseling into the demilitarization of combatants. It requires a commitment to gender integration for DDR programs, literally bringing the wives, partners and children of combatants

53. Theidon, supra note 26, at 32 .

54. See MDRP-Multi-Country Demobilization \& Reintegration Program, Regional Activities, http://www.mdrp.org/regional_act_main.htm (last visited Nov. 30, 2009); see also MDRP-Multi-Country Demobilization \& Reintegration Program, MDRP Launches Learning for Equality, Access and Peace Program, http://www.mdrp.org/PDFs/N\&N _16_07.pdf (last visited Nov. 30, 2009).

55. See Peacebuild-The Canadian Peacebuilding Network, Emerging Issues: Youth, Gender and the Changing Nature of Armed Conflict 13, 15 (2008), http://www.peacebuild.ca/documents/Report-Youth-and-Gender-Conflict-FINAL-draft-ENFeb-29_FINAL.pdf.

56. On the multiple roles of female combatants see generally MirAndA ALisOn, WOMEN and Political Violence: Female Combatants in Ethno-National Conflict (2009). 
where possible into the demobilization space, and utilizing the social connectedness of men to their families and children to affirm individual and group capacity for a different and positive masculinity. It mandates modeling for such men-bringing into the demilitarization space men who have the capacity to act as accepted role models, and who offer a different life perspective, functioning in a post-conflict yet perhaps still violent society. Ultimately, and far more difficult, it requires providing other economic and social opportunities for men to express masculinities in ways that are not socially and politically destructive. As a result, there is a significant overlap between the reconstruction of violent masculinities in post-conflict societies with the provision of meaningful economic opportunities for men (and women).

\section{B. Attention to Male Victimization}

It is also important to acknowledge that men and boys may also have been victimized throughout the conflict, possibly by abduction, possibly by sexual violence as well as the violent ritualization that frequently accompanies male initiation into predominantly male military fraternities. As is generally noted in the context of sexual violence experienced by women, under-reporting is rife in this regard, and we do not have a deep understanding of the form, dynamics and scale of sexual violence that men experience in times of conflict. There is some nascent literature that suggests a link between sexual violence of men by men and deeply rooted practices of feminization. ${ }^{57}$ In this telling, sexual violence experienced by men is a direct playing out of wider social (and violent) practices that are generally directed toward women. For many men who experience rape, the result is to undermine their own masculinity in fundamental ways and put in doubt their sexual identity. Sexual violence experienced by men is, we know, significantly underreported, although empirical proof other than anecdotal evidence is difficult to establish. The statistics of the Peruvian Truth and Reconciliation Commission ("TRC”) suggest that men may underreport (even as the statistics illustrate that women are the most prevalent victims of sexual violence). Of the 538 cases of sexual violence reported to the TRC, 527 correspond to women and only eleven were attributed to male victims. ${ }^{58}$

Equally evident in this context are the unique vulnerabilities of young men and male children who have been conscripted into militias, insurgent

57. UN OCHA, Discussion Paper 2: The Nature, Scope and Motivation for Sexual Violence Against Men and Boys in Armed Conflict 1, 3, 4 (2008), http://ochaonline.un.org/OchaLinkClick.aspx?link=ocha\&docId=1092305.

58. See Colleen Duggan et al., Reparations for Sexual and Reproductive Violence, 2 INT'L J. TRANSITIONAL JUST. 192, 202 (2008). 
groups or paramilitary forces. As the initial indictments from the International Criminal Court illustrate in relation to the harms visited upon child soldiers, acts of sexual violation were intentional and systematic, clearly intended to break bonds between children and their families/communities of origin and force relationships of dependency and shame into the paramilitary organizations. ${ }^{59}$ All of these multiple contexts of male victimization (made more complex by the victims' parallel roles as perpetrators) require melding into the programmatic structure of DDR programs. In particular, DDR programs need to develop special counseling and training programs addressing the harms experienced directly and more broadly, forcing difficult conversations about men's roles post-conflict. ${ }^{60}$

Male victims may feel caught between the hypermasculinization of war and their own feelings of vulnerability and stigma. ${ }^{61}$ Recognizing that gender-based issues are not merely instrumental goals for the benefit of women can help in developing programs to aid this population. These programs might include specially trained counselors, targeted educational opportunities for boy soldiers, and specific health care measures. Like others undergoing the DDR process, they too will benefit from forms of economic empowerment that may help them resolve their feelings of victimization.

\section{CONCLUSION}

There is a need for a fuller recognition that gender cannot be fully addressed in the post-conflict environment by addressing women's rights in legal documents. Gender must be addressed in multiple ways, including through close attention to masculinities as part of the high-priority (and funded) measures to end violence. Programs specifically focused on disarming and reintegrating former combatants need to account for masculinities in their mandates and program deliveries.

Notwithstanding the cultural, legal, and social variations between countries facing post-conflict issues, the core issues around the centrality of

59. See, e.g., Warrant of Arrest, Prosecutor v. Thomas Lubanga Dvilo, Case No. ICC01-02-01/06, (Feb. 10, 2006), available at http://www.icc-cpi.int/iccdocs/doc/doc191959. PDF.

60. See United Nations, Operational Guide to the Integrated Disarmament, DEMOBILIZATION AND REINTEgRATION STANDARDS, OG 5.10, $195-96$ (2006), http://www.unddr.org/iddrs/05/download/IDDRS_510.pdf (last visited Nov. 7, 2009); Megan Bastick, Integrating Gender in Post-Conflict Security Sector Reform, in GeneVA Centre for the Democratic Control of Armed Forces: Policy Paper No. 29, at 18 (2008).

61. See Jeffrey Gettleman, Symbol of Unhealed Congo: Male Rape Victims, N.Y. TimEs, Aug. 5, 2009, at A1, available at http://www.nytimes.com/2009/08/05/world/africa/05congo .html. 
2009] GENDER AND TRANSITION IN CONFLICTED SOCIETIES 123

gender remain universal. In undertaking this analysis, we are convinced that addressing gender and the differing needs of men and women is not only good policy and practice on its own merits, but that it meets the first principle of conflicted and post-conflict societies-namely, ensuring that violence ends for all, is not reignited, and is sustainable far into the future 


\section{HIRSCH LECTURE}

\section{ABSTRACT}

This article uses a gender lens to explore how conflict affects men and women differently. It examines issues related to the emergence of certain kinds of "hyper" masculinity in situations of conflict and how such masculinities continue to function in subsequent peace-building attempts. The article argues that a failure to account for and be cognizant of these specific masculinities has a significant effect for women in particular, and, more generally, on the success of the conflict transition process. Finally, we show how using a gender lens could make a difference by considering the specific example of the impact of violent masculinities on disarmament, demobilization, and reintegration programs.

\section{Gender, Masculinities and Transition in Conflicted Societies1}

The newspapers are filled with information about the countries undergoing transition from conflict to at least formal post-conflict status with the assistance of the international community. Importantly such a transition is not always a move from war to peace - recall Afghanistan, the Congo, Iraq, or arguably Sudan - but, instead, from conflict to less conflict. In this article we seek to explore the role that gender plays in the construction and implementation of the post-conflict transitional process. We focus on examining the gendered dimensions of societies 
emerging from extreme, systematic and institutional violence by multiple parties. Our questions in regard to all of these countries, in all of these varying transition processes, is what we term "the gender question.” Where are women to be seen, and how are they visible within the processes that define and shape the cessation of communal violence? How should peace processes approach the forms of masculinity that dominate in situations of endemic violence? How should peace processes address the emergence of "hyper" masculinity in such contexts? What does the absence of gender signify, and how does such absence affect the substance of any particular agreement (whether local or international) to end violence? How does the failure to properly ask and answer "the gender question" undermine the short, medium and long-term reconstruction of post-conflict societies? 


\begin{abstract}
1 Naomi Cahn is the John Theodore Fey Research Professor of Law, George Washington University Law School; Fionnuala Ní Aoláin is Dorsey \& Whitney Chair in Law, University of Minnesota Law School and Professor of Law and Co-Director Transitional Justice Institute, University of Ulster. We thank the New England School of Law for the opportunity to deliver this lecture, which honours the memories of Anna Hirsch and Mary Jo Frug. This article is drawn from a forthcoming book co-authored with Dina Haynes, New England School of Law, and Dina has been integrally involved in the writing of this article.
\end{abstract}


2 Family law and feminist scholars have noted that the post-war opportunities came with a later backlash in the 1950s with a renewed conservatism about the role of women in society, and a return to fixed roles in a way that reversed many of the earlier advancements. See generally ELAINE TYLER MAY, HOMEWARD BOUND: AMERICAN FAMILIES IN THE COLD WAR ERA (1988); Laura McEnaney, Atomic Age Motherhood: Maternalism and Militarism in the 1950s, in WOMEN'S AMERICA: REFOCUSING THE PAST 448 (Linda K. Kerber \& Jane Sherron De Hart eds., 5th ed. 2000).

3 VeEna DAs, CRITICAl EVENTS: AN ANTHROPOlOGiCAl PERSPECTIVE ON CONTEMPORARY INDIA (2000). 
4 NADERA SHALHOUB-KEVORKIAN, MiLITARIZATION AND ViOLENCE AGAINST WOMEN IN CONFLICT ZONES IN THE MidDLE EAST 645 (2009).

5 In this context Shalhoub-Kevorkian uses the concept of "frontliners," women who occupy parallel and sometimes conflicting roles in violent societies. They are both constrained by highly patriarchal systems but, as a result of the limitations placed on men, have access to and agency within the public sphere. See id.

6 See generally NiRA YUVAL-DAVIS, GENDER AND NATION (1997); JOSHUA S. GOLDSTEIN, WAR AND GENDER: HOW GENDER SHAPES THE WAR SYSTEM AND VICE VERSA (2003).

7 See, e.g., NANCY J. CHOdOROW, FEMININITIES, MASCULINITIES, SEXUALITIES: FREUD AND BEYOND (1994); R.W. CONNELL, GENDER AND POWER: SOCIETY, THE PERSON, AND SEXUAL POLITICS (1987). 
8 See, e.g., Michael S. Kimmel, ManhoOd In AmERiCA: A Cultural History (2005); CONNELL, supra note 7.

9 See, e.g., NANCY E. DOWD, REDEFINING FATHERHOOD (2000).

10 Angela P. Harris, Gender, Violence, Race, and Criminal Justice, 52 STAN. L. REV. 777, 793 (2000). 
11 See GoldsteIn, supra note 6, at 5-6; see also Kimberly Theidon, Transitional Subjects: The Disarmament, Demobilization and Reintegration of Former Combatants in Colombia, 1 INT’L J. TRANS’L JUST. 66, 76 (2007).

12 Theidon, supra note 11 , at 76.

13 Lori Handrahan, Conflict, Gender, Ethnicity and Post-Conflict Reconstruction, 35 SECURITY DiALOGUE 429, 433 (2004). 
14 See generally CHRISTIAN P. SCHERRER, GENOCIDE AND CRISIS IN CENTRAL AFRICA: CONFLICT ROOTS, MASS VIOLENCE AND REGIONAL WAR (2002). 
15 See Brandon Hamber, “We Must be Careful how we Emancipate our Women”: SHIFTING MASCULINITIES IN POST-APARTHEID SOUTH AFRICA, 22-24, 26 (2006),

http://www.brandonhamber.com/publications/Paper\%20Careful\%20how\%20we\%20emancipate.pdf. 
16 Amy Maguire, 'Security Starts with Law': The Role of International Law in the Protection of Women's Security Post-Conflict, in THE Role of InTERNATIONAL LAW IN REBUILDING Societies AFTER CONFLiCT: GREAT EXPECTATIONS 226 (Brett Bowden, et al. eds., 2009).

17 For an analysis of this dynamic in the context of reparations in transitional societies see Ruth Rubio -Marin, The Gender of Reparations in Transitional Societies in THE GENDER OF REPARATIONS - UNSETTLING SEXUAL HIERARCHIES WHILE REDRESSING HUMAN RIGHTS VIOLATIONS 63 (ed Ruth Rubio-Marin 2009) 
18 As of 2008, Somalia’s GDP per capita was \$600; Rwanda’s GDP per capita was \$1000; Burundi’s GDP per capita was \$400; and Columbia’s GDP per capita was $\$ 8,800$. See CIA, THE WorLD FAСТВОOK, https://www.cia.gov/library/publications/the-world-factbook/region/region_afr.html (select a specific country; then select economy).

19 As of January 2009, Rwanda had 55,062 refugees; Somalia had 1,842 refugees and 1,277,200 internally displaced persons; Burundi had 21,093 refugees and 100,000 internally displaced persons; and Columbia had 170 refugees and 3,000,000 internally displaced persons. See UNHCR, http://www.unhcr.org (select the specific country under "browse by country" to view the "Statistical Snapshot”). 
20 Gary Barker \& Christine Ricardo, Young Men and the Construction of Masculinity in Sub-Saharan Africa: Implications for HIV/AIDS, Conflict, and Violence, in SOCIAL DEVELOPMENT PAPERS:

CONFLiCT PREVENTION \& RECONSTRUCTION, PAPER NO. 26, at 31-32 (also published as Social Development Paper No. 84, 2005), available at http://www-

wds.worldbank.org/external/default/WDSContentServer/WDSP/IB/2005/06/23/000012009_2005062

3134235/Rendered/PDF/327120rev0PAPER0AFR0young0men0WP26.pdf.

21 Id. at 12. The limits on access to land in sub-Saharan Africa are pivotal for the transmission of social status, marriage opportunity and independence for young men. 
22 On peace agreements generally see CHRISTINE BELL, PEACE AGREEMENTS AND HUMAN RIGHTS
(2000) 
23 A strong link has been established between disarmament and development. See generally David A. Koplow \& Philip G. Schrag, Carrying a Big Carrot: Linking Multilateral Disarmament and Development Assistance, 91 COlum. L. Rev. 993, 1026-42 (1991); HERBERT WULF, DisARMAMENT AS A CHANCE FOR HUMAN DEVELOPMENT: Is THERE A PEACE DIVIDEND? 1-3 (1992), available at http://hdr.undp.org/en/reports/global/hdr1992/papers/herbert_wulf.pdf.

2 See, e.g. , U.N. Dep’t of Peacekeeping Operations [UNDPKO], Lessons Learned Unit, 4

Disarmament, Demobilization and Reintegration of Ex-combatants in a Peacekeeping 


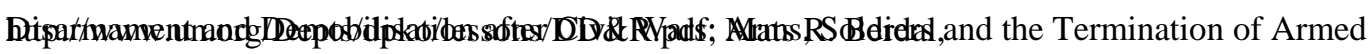
Conflicts

APE 303, at 9, $73-76$ (Int'l Inst. for Strategic Stud., 1996); K $\mathrm{R}$

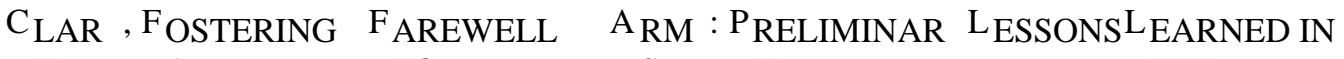

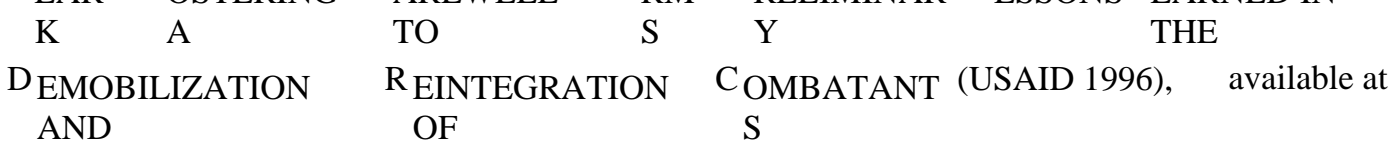

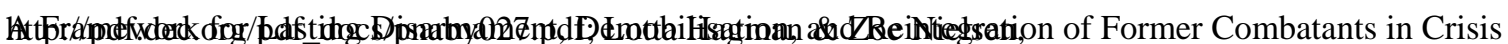
Situations

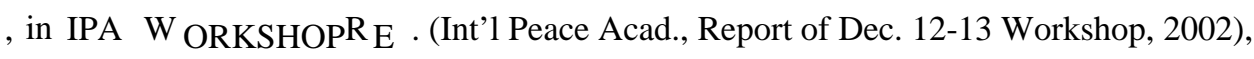
$\mathrm{P}$

available at http://www.ipacademy.org/pdfs/FRAMEWORK_FOR_DDR.pdf; $\quad$ KEES KINGM ,

\begin{tabular}{|c|c|c|c|c|c|c|}
\hline \multirow{2}{*}{\multicolumn{2}{|c|}{ 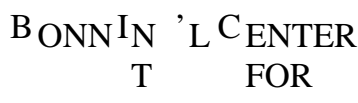 }} & $\mathrm{C}_{\text {ONVERSIO }}, \mathrm{D}_{\mathrm{EM}}$ & OBILISATION & \multicolumn{3}{|c|}{$\mathrm{R}_{\text {EINTEGRATION }} \mathrm{E}_{\mathrm{X}^{-}}$} \\
\hline & & AN & & OF & & \\
\hline COMBATANTS & POS & -WAR AND ${ }^{\mathrm{T}}$ RANSITIO & C OUNTRIE : & $\mathrm{T}_{\text {RENDS }}$ & $\mathrm{C}_{\text {HALLE }}$ & JGES \\
\hline IN & $\mathrm{T}$ & $\mathrm{N}$ & S & AND & OF & \\
\hline
\end{tabular}

EXTERNA S UPPOR passim (2001), available at

L T

http://www.bicc.de/uploads/pdf/publications/other/gtz_studien/demob/demobilisation.pdf; Mark Knight \& Alpaslan Özerdem,

Guns, Camps and Cash: Disarmament, Demobilization and Reinsertion of Former Combatants in Transitions from War to Peace

.499 (2004).

, 41 J. PEACE $\mathrm{P}_{\mathrm{E}}$

$\mathrm{S}$

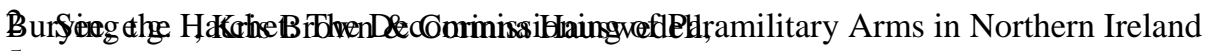

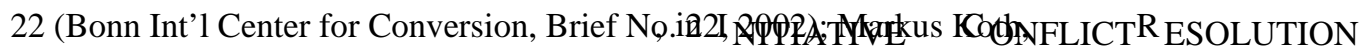

ON AND $Y$

To End a War: Demobilization and Reintegration of Paramilitaries in Colombia, in 


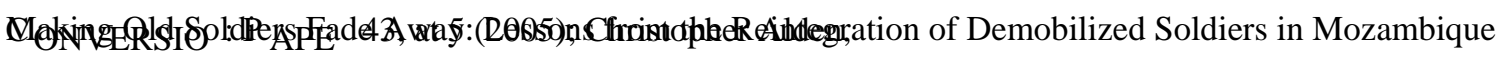
$\mathrm{N}$ $\mathrm{R}$

\section{, 33 S ECURITY}

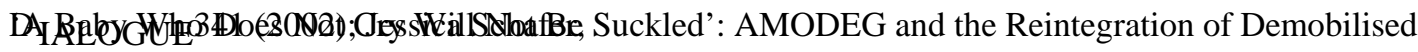
Soldiers

24 J. S. $\quad A_{F} \cdot S_{T U} \cdot 207,208$ (1998).

$$
\mathrm{R} \quad \mathrm{D}
$$

26 Kimberly Theidon, Reconstructing Masculinities: The Disarmament, Demobilization and Reintegration of Former Combatants in Colombia, 31 HUM. RTS. Q. 1, 19 (2009).

27 See UNDPKO, supra note 22, 9 甲 10, 12; Berdal, supra note 22, at 9, 73-76; CLARK, supra note 22, passim; Hagman \& Nielsen, supra note 22, at 1; KINGMA \& BONN INT'L CTR. FOR CONVERSION, supra note 22; Koth, supra note 25, at 25-26; Knight \& Özerdem, supra note 22, passim. 
28 See Fionnuala Ni Aoláin, Women, Security and the Patriarchy of Internationalized Transitional Justice 31 HUMAN RIGHTS QUARTERLY 1055, 1080-1082 (2009).

29 Jason Aplon, Acting Deputy Dir., Office of Dep’t Transition Initiatives, Agency for Int'l Dev., U.S. Dep't of State, Program on States and Security at the Ralph Bunche Institute for International Studies: Post-Conflict Peacebuilding: Connecting Research and Policy (Jan. 25, 2008). See NICOLE BALL \& LUC VAN DE GOOR, DISARMAMENT, DEMOBILIZATION AND REINTEGRATION: MAPPING ISSUES, DILEMMAS AND GUIDING PRINCIPLES 5-6 (2006),

http://www.reliefweb.int/rw/lib.nsf/db900sid/HVAN-6UFKQR/\$file/cling-ddraug2006.pdf?openelement. 
30 See Lisa J. Laplante \& Kimberly Theidon, Transitional Justice in Times of Conflict: Colombia’s Ley de Justicia y Paz, 28 MiCH. J. INT’L L. 49, 57-58 (2006).

31 See BALL \& VAN DE GOOR, supra note 26, at 5-6.

32 Integrated Disarmament, Demobilization and Reintegration Standard, 2.20 Post-conflict Stabilization, Peace-building and Recovery Frameworks, 5-7 (2006), available at http://www.unddr.org/iddrs/02/download/IDDRS_220.pdf .

33 See, e.g., SUSAN MCKAY \& DYAN MAZURANA, WHERE ARE THE GIRLS? GIRLS IN FIGHTING FORCES IN NORTHERN UGANDA, SIERRA LEONE, AND MOZAMBIQUE: THEIR LIVES DURING AND AFTER WAR 98 (2004). 
34 See, e.g., United Nations Office for Disarmament Affairs,

http://www.un.org/disarmament/HomePage/about_us/aboutus.shtml; Escola de Cultura de Pau, DDR 2009: Analysis of Disarmament, Demobilisation and Reintegration (DDR) Programmes in the World During 2008 (2009), available at

http://escolapau.uab.cat/img/programas/desarme/ddr/ddr2009e.pdf.

35 See BALL AND VAN DE GOOR, supra note 26, at 11.

36 For example, Section 8 of the Belfast, or 'Good Friday' Agreement in Northern Ireland deals with security, referring to the "normalisation" of security arrangements and practices. This is to include the reduction of armed forces, the removal of security installations and emergency powers, and other measures appropriate to and compatible with a normal peaceful society. Northern Ireland Office, The Agreement, available at www.nio.gov.uk/the-agreement (follow “Agreement” hyperlink to read the full text of the Agreement) (last visited Nov. 12, 2009). 
37 See Peace Agreement Database at

http://www.transitionaljustice.ulster.ac.uk/peace_agreements_database.html

38 See generally, AMnESTY, HuMAN Rights AND POLITICAL TRANSITIONS: BRIDGING THE PEACE AND JUSTICE DIVIDE (2008) 
39 See U.N. Dept. for Disarmament Affairs in collaboration with the Office of the Special Adviser on Gender Issues and the Advancement of Women, Gender Perspectives on Disarmament, Demobilization, and Reintegration (DDR) (March 2001),

http://www.un.org/disarmament/HomePage/gender/docs/note4.pdf; Theidon, supra note 26.

Brandon Hamber emphasizes the importance of not essentializing men, while recognizing the importance of studying masculinities. Brandon Hamber, Masculinity and Transitional Justice: An Exploratory Essay, 1 INTL. J. TRANSITIONAL J. 375 (2007). 
40 Specifically, according to the UNDP, there are some 550 million small arms circulating in the world today. See United Nations, HUMAN DEV. REPORT 2002, at 97 (2002). Only forty-one percent of these weapons are in the hands of the regular armed forces. See Press Release, European Union, Hans Winkler, State Sec’y, United Nations, “Conflicts Cannot be Resolved Using Arms” (June 26, 2006), available at http://eu2006.gv.at/en/News/Press_Releases/

June/2606WinklerUN.html. Many women express “deep disappointment in the disarmament process.” For example, security threats have impeded women's ability to travel, study, and work in post-Taliban Afghanistan. Human Rights Watch, Between Hope and Fear: Intimidation and Attacks Against Women in Public Life in Afghanistan, Human Rights Watch Briefing Paper, 2, 4 (2004).

41 Notably addressing masculinities requires paying attention to the ways in which women often actively participate in facilitating and supporting men's militarized masculinity. See Theidon, supra note 24, at 29; see also GOLDSTEIN, supra note 6, at 306. 
42 See, e.g., Amnesty International, The Impact of Guns on Women's Lives (2005), available at http://www.amnesty.org/en/library/asset/ACT30/001/2005/en (go to download pdf) (containing a sustained and detailed cross-jurisdictional study of the "ordinary" impact of gun violence against women). The study notes that "although available data supports the widespread assumption that most direct casualties of gun violence are men, particularly young men, women suffer disproportionately from firearms violence, given that they are almost never the buyers, owners or users of such weapons.” Id at 6.

43 Fionnuala Ni Aoláin, Women, Security, and the Patriarchy of Internationalized Transitional Justice, 31 HuM. RTS. Q. 1055 (2009). 
44 U.N. Dev. Fund for Women [UNIFEM], Getting it Right, Doing it Right: Gender and Disarmament, Demobilization and Reintegration 19 (2004), available at

http://www.iknowpolitics.org/files/Getting_it_Right_Doing_it_Right.pdf. 
45 See Sheila Meintjes et Al., There is No Aftermath for Women, in The Aftermath: Women IN POST-CONFLICT TRANSFORMATION 3-18 (Sheila Meintjes et al. eds., 2002). 
46 See supra Part II for further discussion.

47 See Monica MCWilliams et Al., TACKLing DOMestic ViOlence: A POliCy For Northern IRELAND (1995).

48 See, e.g., Anu Pillay, Violence Against Women in the Aftermath in THE AfTERMATH, WoMEN IN POST-CONFLict TRANSFORMATION (Meintjes, Pillay \& Turshen eds., 2002).

49 See Fionnuala NíAoláin \& Catherine Turner, Gender, Truth, and Transition, 16 UCLA WOMEN’s L.J. 229, 252 (2007). 
50 Theidon, supra note 24, at 32.

51 See MDRP_-Multi-Country Demobilization \& Reintegration Program, Regional Activites, http://www.mdrp.org/regional_act_main.htm (last visited Nov. 7, 2009); see also MDRP_MultiCountry Demobilization \& Reintegration Program, MDRP Launces Learning for Equality, Access and Peace Program, Dec. 4, 2007, http://www.mdrp.org/PDFs/N\&N_16_07.pdf (last visited Nov. 7, 2009).

52 See Peacebuild-The Canadian Peacebuilding Network, EMERging Issues; Youth, GENDER AND THE CHANGING NATURE OF ARMED CONFLICT 13, 15 (2008),

http://www.peacebuild.ca/documents/Report-Youth-and-Gender-Conflict-FINAL-draft-EN-Feb29_FINAL.pdf. 
${ }_{53}$ On the multiple roles of female combatants see generally MiRANDA ALISON WOMEN AND POLITICAL VIOLENCE: FEMALE COMBATANTS IN ETHNO-NATIONAL CONFLICT (2009) 
54 UN OCHA, Discussion PAPER 2: THE NATURE, SCOPE AND MOTIVATION FOR SEXUAL VIOLENCE AGAinst MEN AND BOYS IN ARMED CONFLICT 1, 3, 4 (2008),

http://ochaonline.un.org/OchaLinkClick.aspx?link=ocha\&docId=1092305. 
55 See Colleen Duggan et al., Reparations for Sexual and Reproductive Violence, 2 INT’L J. TRANSITIONAL JUST.192, 202 (2008).

56 See, e.g., Prosecutor v. Thomas Lubanga Dvilo, Case No. ICC-01-02-01/06, Warrant of Arrest (Feb. 10, 2006), available at http://www.icc-cpi.int/iccdocs/doc/doc191959.PDF

57 See UnITED NATIONS, OpERATIONAL GUIDE TO THE INTEGRATED DiSARMAMENT, DEMOBILIZATION AND REINTEGRATION STANDARDS, OG 5.10, 195-96 (2006),

http://www.unddr/prg/iddrs/og/OG_5_10.pdf (last visited Nov. 7, 2009); Megan Bastick, Integrating Gender in Post-Conflict Security Sector Reform, in GENEVA CENTRE FOR THE DEMOCRATIC CONTROL OF ARMED FORCES: POLICY PAPER NO. 29, at 18 (2008). 
58 See Jeffrey Gettleman, Symbol of Unhealed Congo: Male Rape Victims, N.Y. TIMES, Aug. 5, 2009, http://www.nytimes.com/2009/08/05/world/africa/05congo.html. 

In this article, we first explore how conflict affects men and women differently, and introduce the gender lens that we use throughout our analysis. We then examine issues related to the emergence of certain kinds of "hyper" masculinity in situations of conflict and in the subsequent peace-building attempts. Next, we argue that a failure to account for and be cognizant of these specific masculinities has a significant effect for women in particular, but generally on the success of the conflict transition process. Finally, we show how using a gender lens could make a difference by considering the specific example of the impact of violent masculinities on disarmament, demobilization, and reintegration (“DDR”) programs.

\section{Conflict and Gender: Women}

Conflicts affect both men and women, but women face additional issues during and after wars that men do not, including pervasive sexual violence, forced impregnation, reproductive violence, sexually transmitted diseases, and forced abortion. Women and their children experience internal displacement and dominate the refugee populations across conflicts. Women 
are also differentially affected because of their role as the primary caretaker of the household and family. In this regard, traditional gender dichotomies may be further entrenched and exacerbated during times of extreme violence. Surprisingly, the transitions born of conflict may yield positive social, economic and political changes for women. For example, during some conflicts in which aspects of a functioning state and economy continue to exist, women can take on roles as workers and laborers outside of the home, opportunities which would never be available were the society not in conflict. Rosie the Riveter, the archetypal woman who was employed in the Second World War to help with the military effort, and subsequently transformed the war experience into economic opportunity in the post-war period for women, exemplifies a well-known American illustration of this phenomenon.2 
Despite these potentially positive aspects, in most contexts the result of conflict for most women is a negative sum. Economies stall during and after conflict or operate in black and grey markets where women are the least often employed or employable, because of their legally enforced second-class status. Across most post-conflict transitions, women are the first to be fired and the last to be hired with the large exception of the false (and temporary) economy built up around the presence of the international community, in which women are paid to fill the "camp follower" positions as housekeepers, cooks administrative positions and, of course, for sex. Women and children also constitute the overwhelming number of refugees, of people displaced from their home communities. The very fact of war can contribute to undermining the limited social stability and security of women in many societies that is the precursor to any exertion of economic or social autonomy.

We stress that women's roles cannot be essentialized, even in the context of war. Women are frequently violent actors themselves in violent and conflicted societies, both in undertaking primary acts of violence and violation or lending substantial support to men who carry out such actions. Importantly, recognizing that women can be violent has practical consequences. For example, it provides the means to recognize that women who have also been combatants face an array of social and cultural challenges that simply never arise for men during and after war. Accepting and accommodating a more diverse range of roles for women both in war and post-war facilitates a greater conceptual and practical understanding of the lived intersectionalities of most women's lives. Equally, a practice of gendering our analysis of violence thus "cannot be conceptualized without understanding the process of knowledge production as such epistemic 


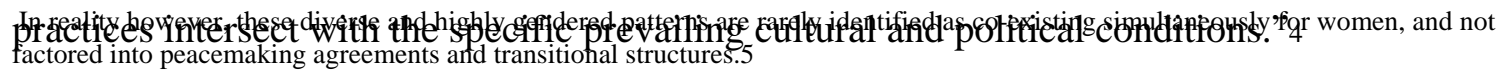

\section{Conflict and Gender: Men}

A fairly substantial amount of literature has been generated over the years regarding the forms of masculinity that emerge in times of armed conflict and war.6

Theorists have identified an organic link between patriarchy, its contemporary outworkings and various forms of masculinity as they arise within societies and institutions. A preponderance of literature across disciplines has deepened our understanding of how masculinities are constructed and differentiated.7

While a war literature across many disciplines has made significant use of the conceptual and practical consequences of the term "masculinity," the term has been less applied 
and understood to be relevant in the post-conflict context. We suggest that masculinities study is a diverse and burgeoning field, which has significant insights to offer to the analysis we wish to advance here.8

Masculinity theorists and feminist analysis have not always worked in tandem, and it is only relatively recently that feminist scholars have sought to address what masculinity studies has to offer feminist theorizing.9

In this vein, we start from asking the related "man" question, interrogating where and how men are situated in relation to the creation, perpetration and institutionalization of violence. In what ways does hegemonic masculinity work, and how do masculinities operate to benefit even those men who are at the margins of masculinity norms and practice? We learn that even within the hierarchies of masculinity, subordinated masculinities benefit from the social construction of male privilege and value. While an enormous amount of scholarship has been generated about the varying forms of masculinity and their effects, of particular interest to our analysis is the lens of "hyper" masculinity.

In our emphasis on hyper masculinity we draw on Angela Harris' definition of "a masculinity in which the strictures against femininity and homosexuality are especially intense and in which physical strength and aggressiveness are paramount.”10

We frame our analysis by affirming that other kinds of masculinities coexist with hyper masculinity, but notably in situations of conflict and endemic violence, hyper masculinity plays an enlarged and elevated role. Its social traction is intensified when violence is endemic, and other social strictures are 
One clear analogy for non-conflicted states is to analogize the emergence of hyper masculinity with the role of the military in multiple cultures and societies. The military is closely tied with manhood, and, indeed, militaristic actions are supported by an ideology of male toughness.11 Self-evidently, men dominate most national and international militaries. By the time the conflict ends, men who have acted militarily and the (generally) male political elite are deeply enmeshed in this cultural vision of manhood. As former combatants in Colombia explained to anthropologist Kimberly Theidon, for example, joining a paramilitary group allowed the men "to 'feel like a big man in the streets of their barrios,' to 'go out with the prettiest young women,' and to 'dress well,' privileges they insist would not have been possible if they weren't carrying a gun." 12 We suggest that the prevalence of this kind of masculinity poses complex issues for undoing violence, for mainstreaming gender equality and for remaking societies that have been fractured and deeply divided.

The post-conflict environment, like conflict, is also "vividly about male power systems, struggles and identity formation."13

There may be an enormous flux in the male post-conflict fraternity both on an individual and communal level. Moreover, international organizations and 
Post-conflict societies present a unique and under-analyzed site of examination for masculinities. One of the main reasons for the lack of attention to masculinities in this domain has been the presumption that the post-conflict context is equated to peace and that the absence of war makes moot any analysis of masculinity, which may be presumed "tamed" by the end of violent contestation. This presumption fails to account for the ways in which women experience violence both in conflicted and post-conflict societies. The result of this lack of attention to masculinities means a failure to account for the myriad of ways in which masculinities transform, adapt and reformulate in the post-conflict environment. Consequently, close attention to the forms and impact of masculinities in the post-conflict milieu is critical not only for women's experiences in the postconflict domain, but also for the success of the transition process.

One enduring question that emerges from the conflict and masculinities literature is why men engage in violence? Without over digressing, we point out that violence as an aspect of masculinity is deeply linked to the assertion of social status and the value of self in particular contexts. Violence may literally "make the man" in many societies, and not infrequently the site of the violence is the woman's body. In recognizing such deeply rooted links between the constructions of the masculine self, and the social acceptance of the "man" as valued, we acknowledge the difficulties that arise as we address the end of violence (as a formal legal matter). A clear corollary of this analysis is noting that the end of violence is not a superficial 
engagement, but may require deep and difficult entanglement with the masculine construction of self in many societies. In post-conflict societies such conundrums are compounded by the lack of other opportunities available to men to assert positive masculinities, and to have practical and symbolic roles within societies that struggle on the economic margins and are deeply politically dysfunctional.

This question of violence and its end is central to the post-conflict experience because the cessation of public violence between (generally) male combatants is usually the litmus test by which the success of transition from war to peace is measured. We take issue with the presumption that the end of public violence and the measurement of security based on the safety of male combatants constitute an adequate calculation of peace in any society. Nonetheless, we accept that analysis of the causality of violence is central to addressing transformation in the post-conflict environment holistically. Any answer to the causality question is extremely complex and resultantly variables between social and cultural contexts are inevitable. It is, we think, also made more complicated by a deeper recognition of the role that masculinities play in giving rise to violence, and the difficulties of transforming such practices on a fundamental level. Nonetheless, greater attention to causality is entirely relevant to addressing women's experience of violence as well as implanting measures in post-conflict societies that meaningfully address the needs for women's security.

The causes of violence and conflict in a range of societies are far too complex to explore here.14

But a number of cluster causalities are useful to identify. First, is economic and social insecurity; second, a lack of legal and political status particularly associated with group or ethnic 
identity; third, the lack of opportunity for meaningful self-determination (whether external or internal) within the state. In multiple contexts, engaging in violence is a rational choice for men when few other opportunities may be provided to gain economic security (albeit that

participation in violence provides a highly tenuous economic existence or longevity), social status and value within their communities, and security (again albeit tenuous and fragile) for their families and communities. We suggest, as other post-conflict literature has begun to explore, that there is a strong overlap between all these causal categories and the emergence of certain forms of masculinity in conflicted societies. We note that without addressing the causalities outlined above in a frame that substantively weaves in masculinities, we may also fail to address the ongoing realities of masculinities as they closely interconnect with post-conflict social, political and economic outcomes.

Beyond a more nuanced recognition of international masculinities, we also want to address a more complex set of role assumptions for men and women in post-conflict societies. It requires asking a fundamental question of what does it mean, "to be a man" in a violent society, when

violence begets status and economic capacity? Even more relevant to our inquiry, what happens to such masculinities when societies transition from violence and move towards democratic or more liberal forms of political engagement? Which men loose and gain in such contexts? As both Brandon Hamber and Amy Maguire have explored in transitionary Lebanon and post-apartheid South Africa, women often bear the brunt of the flux in masculine roles.15 
I think, in as much as the law of the country allows women to be empowered, that is going to have a spin-off effect on men's behaviour and men's attitude towards women. In particular, those so-called empowered women. They'll always be the subject of abuse ... everywhere you go .... if you are perceived to be an empowered woman you are subject to a lot of abuse from society in general.16

The link between formal (generally equality) gains made by women in many post-conflict legislative and constitutional enactments conjoined with the political displacement of power for many men from the traditional routes provided during armed conflict creates a complex social and legal terrain. It is upon this territory that women's gains and their intersection with masculinities in flux are played out. We need to be attuned to the reality that formal gains for women may, in fact, be nullified or significantly constrained by the reality of social and community context, in which the accommodation of men's deeply entrenched social status may outweigh the enforcement of formal legal norms in practice. 17 
It is also vital to contextualize the reality of economic fragility faced in post-conflict zones around the world. Countries emerging from conflict are some of the poorest on the planet.18

They have the highest number of refugee populations (who are predominantly female with child dependents) and internally displaced persons.19

In this context, when one domain of status and economic subsistence is closed off (by the end of violent armed conflict) such societies struggle to replace the dysfunctional economy of war with a functional liberal economy of provision. The tools that for some men provided a means of

survival in war are unreliable and may no longer be needed. Men and young boys who are under or uneducated are at a considerable and materia disadvantage in such settings. In this space of economic struggle, Barker and Ricardo illustrate the rise in the parallel economics of criminality and "normal" violence, which allow certain forms of masculinity to endure and to provide both status and 


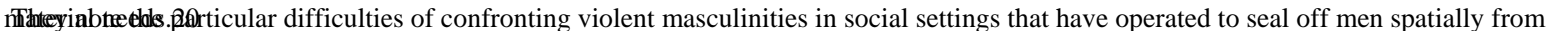
women and children. This is further compounded in societies that have deeply stratified gender roles leaving little room for the enablement of positive masculinities in either the public or private sphere. The effects of such stratification are also intensified when one accounts for intergenerational transmission of violent norms, as well as in societies where age stratification is intense, creating intense competition for economic and sexual resources as well as opportunities.21

\section{The Gender Lens}

Having explored how conflict affects both men and women, we want to affirm the importance of a gender lens, and investigate its impact. It may not appear self-evident, but the importance of affirming the independent value of a gendered assessment of post-conflict processes remains contested. In this legal and political space of ending or transmuting conflict, women still struggle to assert the importance of issues that affect them directly. They remain subordinated by dominant discourses that minimize or ignore the value of placing the needs and 
views of women at the center of the conversation about ending violent communal behaviors, even though such placement is absolutely central to ending societal violence. It needs constant restatement that women are the group most historically marginalized and excluded from the peacemaking and peace-building process across all jurisdictions and conflicts.22

We assert that applying the gender lens is a means to make more effective the policies and practices involved in ending conflicts and ensuring that they do not recur. In this regard traditional gender dichotomies may be further entrenched and exacerbated during times of extreme violence.

While women are missing from key roles in peace negotiations and government, they often dominate in civil society movements that create "safe" and neutral spaces in conflicted societies. In this latter role, women often provide the grassroots networking and social support structures that are relied upon by local and international elites to embed peace processes. But within this expectation the question must be asked whether the internationals and others are essentializing the women on whom they so rely, of reducing and collapsing their varied roles into a single dimension by relegating them to "soft" civil society roles, rather than tangible roles entrenched in the political infrastructure. We remain consistently wary of essentializing women as peacemakers and facilitators when we are deeply aware of the complex set of roles women as individuals and as members of broader communities play in enabling and encouraging violence. Such essentialization also underplays the extent to which women play an under-appreciated role in supporting and enabling certain kinds of masculinities to thrive.

Using the gender lens helps us understand that gender must become central to conflict resolution, peace-keeping, reconstruction, and reconciliation efforts. Integrating gender into the 
post-conflict process is insufficient unless gender is incorporated into all aspects and levels of the newly developing or rehabilitating state. For gender to be absolutely involved it must be addressed in every issue and at every level. In this view, is it in sufficient for formal legal norms alone to confront the inequalities, violence and discrimination that women may have experienced during conflict.

Rather, a broadly framed set of imperatives is required which includes legal reform to address harm and exclusion but takes account of the broader psycho-social and customary practices that we have identified in the context of our analysis of masculinity in action. For example, gender centrality has often focused almost exclusively on holding war crimes perpetrators accountable for sexual violence. We cannot, however, evaluate the credibility and value of such accountability mechanisms without an eye to the broader transitional and gendered dynamic of the society in question. Moreover, we cannot hope to dislodge practices of violence to women (before, during and after conflict) unless we are prepared for a hard interface with the social embeddings of violence in the individual identities and social practices of men.

In its broader context, our approach challenges conventional notions concerning the role, and rule, of law in post-conflict situations. For those of us trained to think in terms of legal solutions, of justice via international, regional, or local tribunals, of prosecutions and investigations and evidence and trials, these concepts must be tested in countries with a minimally functioning justice system, with no means of protecting victim-witnesses, and with only minimal assurance that genocide and gender-based violence will not recur. In these countries, we must be particularly sensitive to what role the law can and should play in ending impunity and restoring confidence that the war wounds can be healed. An emphasis on the relationship between masculinities and violence in conflicted and post-conflict societies enables us to identify a much broader array of enabling phenomena resulting in women's experiences of 
systematic violence. In doing so, we become acutely aware that formal legal mechanisms provide only part of the solution.

Finding justice for victims and punishing perpetrators are critical, but there are important contextual issues on how best to proceed to ensure that these occur as countries struggle to establish new governments. In our focus on legal approaches, we must remember the practical realities that confront victims of gender-based violence as they continue with their lives, often living in the same communities as the perpetrators, and thus craft remedies that account for these differing, potentially conflicting, realities which themselves may reflect divergent constituencies: a need for punishment, a need for rehabilitation for both victims and perpetrators, and a need for moving on politically in a divided society.

\section{Sites of Masculinity Struggle in the Post-Conflict Environment -Disarmament, Demilitarization, and Reintegration}

To show how a gender lens might matter, we turn to the process of Disarmament, Demilitarization and Reintegration (DDR). DDR efforts are integral parts of development aid and peace-making processes in multiple conflict situations.23

An extensive general literature has emerged on the subject of DDR,24 
particular countries and how they have reintegrated and demobilized (or not) former combatants.25

DDR comes with strong instrumental and policy goals. At its essence it may 
function as the most important preliminary step in ending or limiting violent conflict. It can act instrumentally to facilitate control over armed forces (both state and non-state). Less obviously, DDR can create extraordinary vulnerabilities in societies where guns are "both a threat

Thus, addressing the full spectrum of gendered issues for men and women is a complex and highly variable task. The demobilization, demilitarization and reintegration of former combatants clearly overlap with the production, control and maintenance of masculinities in conflicted and post-conflict societies.

DDR programs do not follow one template, but they are typically discussed during the peace process and established after the peace accord has been signed, as one of the first components of implementation.27

Recall that women are significantly absent or excluded from the peace making process. Moreover, even where women are present to peace negotiations, the specific negotiation sites in which demilitarization and security are agreed tend to be exclusively male and lack gender parity in representation going hand in hand with the reality of women's 
Examples of the integration of demilitarization with the formal peace deal include the Good Friday Peace Agreement in Northern Ireland, various versions of the Colombian peace process and the demilitarization of former combatants in Mozambique. It is generally agreed that DDR programs should only be undertaken with certain conditions present, such as a peace accord that establishes the framework for DDR, a general sense of confidence in the peace process itself; minimal and meaningful levels of security, ownership of DDR by all relevant stakeholders; and basic guarantees of information and transparency.29

Given the fractured nature, form, and implementation of peace agreements, however, this rarely happens.

Traditional or "classical” DDR programs, which assume ideal—and rare—conditions, conceive of DDR as a set of technical interventions to assure, for example, effective containment of armed groups, collection and destruction of weapons, division of former combatants into those who will remain in or join the country's armed forces and those to be demobilized, and then the effective reinsertion, reintegration, and rehabilitation of those demobilized into their 
CDhembovities pfintigific30irse, is that there is a variance of emphasis across most DDR implementations, but a general pattern is that demobilization gains considerable and quick traction while the reintegration and rehabilitation portion draws much less reflection, funding, and applied enforcement from the state and the international community. DDR requires some minimal levels of security as a baseline for establishing the institutional structure for disarmament and for making former combatants feel safe in relinquishing their weapons. It also requires that all parties, including the former combatants and new government as well as international actors, commit to its implementation, with consensus as to the basic outline of the process.31

The most intensive operations occur post-stabilization, during the transition and recovery period.32

The actual implementation often starts with combatants voluntarily entering reception centers to turn in arms to begin the demilitarization process.33

Such programs are typically administered by a multilateral organization and/or the United Nations, and the World Bank and 


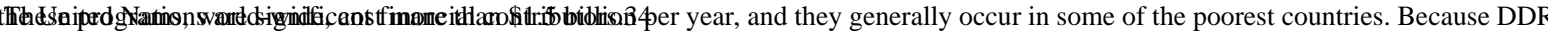
processes depend on broader developments towards a peaceful environment, they are subject to frequent disruptions, and they seldom proceed in a linear fashion.35

The presence or absence of DDR raises complex questions in post-conflict or regime change societies from a gender perspective. For example, disarmament has a high crossover with political decisions and compromises involving amnesty for human rights and humanitarian law violations, including amnesty for crimes involving sexual violence or violence against women.36

To make the obvious point, in contexts where women are the least likely to be present at the negotiation, deals are struck that include amnesty for crimes involving sexual violation, mutilation, reproductive 


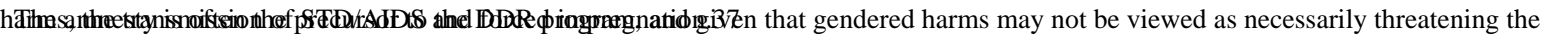
growing international consensus that certain crimes against humanity cannot be subject to amnesty,38

the gendered fault line may simply not be noticed or assessed as a fundamental bias to such processes. This challenging nexus between gende and disarmament is important to highlight. Political compromises, including amnesty for serious human rights violations that have occurred during a conflict, mostly made by elite men, often fail to engage with the particular vulnerabilities created for women by partial or excluded accountability.

Gender perspectives are important to DDR for numerous reasons. First, armed conflict affects women and men differently, and that difference is seldom taken into account in designing and implementing DDR programs. The obvious point being that women are often hugely affected in their day-to-day lives by the way in which a DDR program is implemented. The range of effects include the front line exclusions that fail to accommodate women in compensation schemes and the internal effects with may include the return of violent men to their communities, with little if any recognition of the potential harms that they may visit on their home environments, and little if any support to victims when subsequent harms occur. Second, under many existing programs, women and men have unequal access to resources following conflict. Particularly in light of the gender biases and inequalities in most societies, DDR may be focused on male combatants. What this means in practice, is that the economic benefits that flow 
$+2$

$=$ 
Accordingly, using a gender perspective leads to a series of additional issues that arise concerning the structure of DDR programs. First, what constitutes disarmament sufficient to satisfy a ceasefire requirement in the political/military sense may not in fact entail the removal of all such weapons from the public, and more importantly the private sphere.40

An obvious linking issue is how to measure the success or failure of demobilization from a gender perspective. This benchmarking for success through a gender sensitive lens is markedly absent through many of the programs that are heralded as success stories by the international

community. Second, demobilization generally fails to address the deep imprinting of violent masculinities in former combatants and the effects of a militaristic culture on the civilians that surround him in the transitional and post conflict context.41 
dimensions which, in a conflicted society, have supported the resort to violence, and the elevation of particular forms of masculinity that accompany it, are not in any sense undermined or addressed by a formal demobilization process. Thus, a key issue to be addressed concerning violence is what is meant by the term “ending violence.” In the parlance of ending public violence or internal conflict this conversation revolves around decommissioning weapons, getting armed paramilitaries/insurgents to swap violent confrontation for peaceful debate about contested issues. However, this kind of discussion rarely engages with the fundamental requirement of changing deep-seated social attitudes toward the use of violence.42

Self-evidently, where discharged-but-not-disarmed combatants return to their homes and families with their weapons, the sites of violence may simply move from the public to the private sphere.43

\section{Attention to Masculinities}

As societies transition from violence and move towards democratic or more liberal forms of political engagement, close attention must be paid to masculinities as part of the project of ending violence. Failure to account for and be cognizant of these specific masculinities has 
significant effects for women, but more generally on the success of the conflict transition processes.DDR programs struggle with "what to do with the 'morass of malignant male muscle' ... . Men unable to positively manifest masculine roles may return to violent and destructive means of expressing their identities." 44

Factoring this psychosocial reality into the design and implementation of DDR programs is a means to avert inevitable structural barriers to the success of a key element of conflict-ending processes.

Masculinities appear in several different ways throughout the DDR and other processes. First, socialization into male roles as both traditional head of household and then, as a result of the conflict, into the assumption of violent roles, may be difficult to undo. We stress that the complexity and difficulty of this task should not be underestimated by policy-makers, but underscore the immediate and inter-generational benefits that processes and policies sensitively attuned to the dynamics of embedded socialization will reap in the long-term.

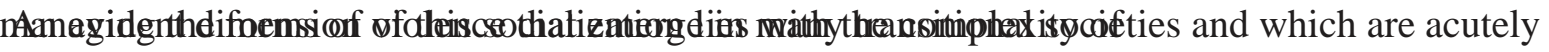
illustrated in the relationship between disarmament and intimate violence. As a starting point, underlying endemic sexual and domestic violence is never calculated into an overall accounting for the experience of violence during conflict. There is a strong and maintained presumption that sexual violence in war is a thing apart, an experience capable of being parsed out from the "regular and normal" violence that accompany women's lives in many societies. As feminist international scholars have long noted, sexual and gender-based violence rarely conforms to the timelines of 
peace treaties and ceasefires but endures past them. The kinds of violence and sexual acts perpetrated upon women in conflicted societies endure as a form of entrenched "othering" in such societies, and pervades the way in which women subsequently experience inequality, discrimination and exclusion. Many observers and commentators on post conflict societies have asserted that there is a marked rise in the violence which women experience postconflict.45

Statistics in a number of post-conflict societies that measure such acts suggest, at least, a marked increase in reported violence. The empirical evidence for such an overarching trend is not fully demonstrated, but at the very least there is room to acknowledge the continued pervasiveness of violence for women when peace is theoretically won. This confirmation undoes a pervading premise that women and men experience the postconflict gains in the same way.

\section{Re-Socializing Men}

One of the central quandaries for the DDR process is how to undo the masculinities learned during wartime. Where discharged combatants return to their homes and families, the sites of violence may simply move from the public to the private sphere. From the gendered critique of accountability mechanisms, what we learn is that truth processes may examine the prior violence in the public sphere, but will not engage in any way with the continual violence that is facilitated in the private sphere by non-rehabilitated former combatants. The disconnect between the operation and scope of the transitional justice mechanism and the intimate and everyday realities of living with a former combatant for women could hardly be more starkly contrasted.

This disconnect has been graphically identified in such transitional societies as South 

Affrgeample, the perceived escalation of domestic violence rates post-apartheid have raised deep concerns about the relationship between pre-
existing apartheid violence and its spill-over to a transitional society. There is evidence that post-conflict societies do (at least) statistically experience greater proportions of domestic and intimate violence.47

Thus, increased reporting at the end of conflict may not mean absolute empirical increases in violence per se; rather it may simply mean that reporting is possible where it was not previously, and in fact, the forms of violence may be more muted. Nonetheless, while it remains open to further empirical investigation to assess the fullness of the relationship between violence during conflict and increased violence post-conflict, what remains clear is that there is a continuum of violence for women and that the end of conflict is not the end of gendered violence. The normality of ongoing violence for women is itself broadly sustained through political transformations.

The reassertion of violence in the private sphere during the transitional phase may constitute a form of compensation for male combatants, for their loss of public status and hegemony.48 This is graphically shown by the psychological phenomena of the returning warrior who has, through conflict, normalized the use of violence and views the home as another site in which to exercise power and control through physical force.49 
DDR programs can help to separate manhood from its violent and military meaning by providing positive, non-violent role models and means for achieving status. Kimberly Theidon observes that many of the former combatants in Colombia told her they were "tired" of combat; she suggests that "the DDR program [could] make more explicit what these men gain in the transition from combatant to civilian.”50

In the Congo, for example, the DDR program is collecting information on how programs that involve men can dissolve gender stereotypes.51

Offering vocational education and creating employment opportunities in both the public and private sectors can serve to channel aggressive energy into more productive uses.52

It is also evident that the integration of men more positively into their family and parenting roles offers some means to redress the complex roles that men must manage in the post-conflict context. Here, relatively simple moves, such as ensuring that families and children are integrated into the DDR process, can operate as positive transitionary measures to support both men and women and open up spaces for social transformation. Another important and related move is to extend 
and broaden the categories of combatant for the purposes of DDR programs, ensuring that women who have provided support roles to military or paramilitary forces (as well as women who have been involved in direct hostilities) be included and fully integrated into structured DDR programs.53

This would assist both in ensuring that women combatants are not doubly marginalized by their involvement in military and paramilitary organizations, and that the opportunity is provided to affirm the status of women combatants (who frequently languish and suffer the postconflict stigma of non-conforming gender roles as society returns to "normal") and to include women fully in the benefits that flow materially and otherwise from demilitarization.

Re-socializing men requires integrating the information known about the effects of hyper and other forms of heightened masculinities into the planning and delivery of what are generally internationally constructed and supported DDR programs. It means moving the emphasis away from merely handing over guns to neutral arbitrators and instead integrating psychological and reflective counseling into the demilitarization of

combatants. It requires a commitment to gender integration for DDR programs, literally bringing the wives, partners and children of combatants combatants. It requires a commitment to gender integration for DDR programs, literally bringing the wives, partners and children of combatants
where possible into the demobilization space, and utilizing the social connectedness of men to their families and children to affirm individual and where possible into the demobilization space, and utilizing the social connectedness of men to their families and children to affirm individual and
group capacity for a different and positive masculinity. It mandates modeling for such men- bringing into the demilitarization space men who have the capacity to act as accepted role models, and who offer a different lived perspective functioning in a post-conflict yet perhaps still violent society. Ultimately, and far more difficult, it requires providing other economic and social opportunities for men to express masculinities in 
ways that are not socially and politically destructive. As a result, there is a significant overlap between the reconstruction of masculinities of violence in post-conflict societies with the provision of meaningful economic opportunities for men (and women).

\section{Attention to Male Victimization}

It is also important to acknowledge that men and boys may also have been victimized throughout the conflict, possibly by abduction, possibly by sexual violence as well as by the violent ritualization that frequently accompanies male initiation into predominantly male military fraternities. As is generally noted in the context of sexual violence experienced by women, under-reporting is rife in this regard, and we do not have a deep understanding of the form, dynamics and scale of sexual violence that men experience in times of conflict. There is some nascent literature that suggests a link between sexual violence of men by men and deeply rooted practices of feminization.54

For many men who experience rape, the result is to undermine their own masculinity in fundamental ways and put in doubt their sexual identity. Sexual violence experienced by men is, we know, significantly underreported. The Peruvian Truth and Reconciliation Commission ("TRC”) illustrates the point about under-reporting in general (and of women as the most prevalent 
Equally evident in this context are the unique vulnerabilities of young men and male children who have been conscripted into militias, insurgent groups or paramilitary forces. As the initial indictments from the International Criminal Court illustrate in relation to the harms visited upon child soldiers, acts of sexual violation were intentional and systematic, clearly intended to break bonds between children and their families/communities of origin and force relationships of dependency and shame into the paramilitary organizations.56 All of these multiple contexts of male victimization (made more complex by the victims' parallel roles as perpetrators) require melding into the programmatic structure of DDR programs. In particular, DDR programs need to develop special counseling and training programs addressing the harms experienced directly and more broadly, forcing difficult conversations about men's roles post-conflict.57 
Male victims may feel caught between the hyper-masculinization of war and their own feelings of vulnerability and stigma.58 Recognizing that gender-based issues are not merely instrumental goals for the benefit of women can help in developing programs to aid this population. These programs might include specially trained counselors, targeted educational opportunities for boy soldiers, and specific health care measures. Like others undergoing the DDR process, they too will benefit from forms of economic empowerment that may help them resolve their feelings of victimization.

\section{Conclusion}

There is a need for a fuller recognition that gender cannot be fully addressed in the post-conflict environment by addressing women's rights in legal documents. Gender must be addressed in multiple ways, including through close attention to masculinities as part of the high-priority (and funded) measures to end violence. Programs specifically focused on disarming and reintegrating former combatants need to account for masculinities in their mandates and program deliveries.

Notwithstanding the cultural, legal, and social variations between countries facing post-conflict issues, the core issues around the centrality of gender remain universal. In undertaking this analysis, we are convinced that addressing gender and the differing needs of men and women is not only good policy and practice on its own merits, but that it meets the first principle of conflicted and post-conflict societies - namely, ensuring that violence ends for all, is not reignited, and is sustainable far into the future. 